\title{
Arsenic trioxide induces a beclin-1-independent autophagic pathway via modulation of SnoN/SkiL expression in ovarian carcinoma cells
}

\author{
DM Smith ${ }^{1}$, S Patel ${ }^{1}$, F Raffoul ${ }^{1}$, E Haller ${ }^{2}$, GB Mills ${ }^{3}$ and M Nanjundan ${ }^{\star, 1}$
}

\begin{abstract}
Arsenic trioxide $\left(\mathrm{As}_{2} \mathrm{O}_{3}\right)$, used to treat promyelocytic leukemia, triggers cell death through unknown mechanisms. To further our understanding of $\mathrm{As}_{2} \mathrm{O}_{3}$-induced death, we analyzed its effects on transforming growth factor- $\beta$ (TGF $\beta$ ) signaling mediators in ovarian cells. Dysregulated TGF $\beta$ signaling is a characteristic of ovarian cancers. $\mathrm{As}_{2} \mathrm{O}_{3}$ reduced the protein expression of EVI1, TAK1, SMAD2/3, and TGF $\beta$ RIl while increasing SnoN/SkiL. EVI1 protein was modulated by treatment with the proteasome inhibitors, MG132 and PS-341/Velcade, suggesting that degradation occurs through the ubiquitin-proteasome pathway. The sensitivity of ovarian cells to $\mathrm{As}_{2} \mathrm{O}_{3}$-induced apoptosis correlated with expression of multidrug resistance protein 1 . Interestingly, expression of SnoN was similar to LC3-II (autophagy marker), which increased with induction of cytoplasmic vacuolation preceding apoptosis. These vesicles were identified as autophagosomes based on transmission electron microscopy and immunofluorescence staining with EGFP-LC3. The addition of $\mathrm{N}$-acetyl-L-cysteine (ROS scavenger) to $\mathrm{As}_{2} \mathrm{O}_{3^{-}}$ treated cells reversed changes in SnoN protein and the autophagic/apoptotic response. In contrast to beclin-1 knockdown, siRNA targeting ATG5, ATG7, and hVps34 markedly reduced autophagy in $\mathrm{As}_{2} \mathrm{O}_{3}$-treated ovarian carcinoma cells. Further, treatment with SnON siRNA markedly decreased LC3-II levels and increased PARP degradation (an apoptosis marker). Collectively, these findings suggest that $\mathrm{As}_{2} \mathrm{O}_{3}$ induces a beclin-1-independent autophagic pathway in ovarian carcinoma cells and implicates SnoN in promoting $\mathrm{As}_{2} \mathrm{O}_{3}$-mediated autophagic cell survival.
\end{abstract}

Cell Death and Differentiation (2010) 17, 1867-1881; doi:10.1038/cdd.2010.53; published online 28 May 2010

Ovarian cancer is the fifth most common cancer in women with approximately 22000 new cases and 15000 deaths each year in the United States based on National Cancer Institute statistics. Although advances in surgery and chemotherapy have improved the survival rate, the development of resistance to chemotherapy continues to be a challenging clinical problem in the treatment of advanced stage ovarian carcinoma. Thus, greater effort is needed to identify novel therapeutic targets and treatment strategies. Targeting signaling pathways that are dysregulated in cancer, such as those mediated by transforming growth factor-beta (TGF $\beta)$, is one approach to improving patient survival. TGF $\beta$ mediates both tumorsuppressing and tumor-promoting activities by (1) repressing transformation in normal cells and (2) increasing aggressiveness of transformed cells through induction of epithelial- mesenchymal transition (EMT), which leads to increased invasion and metastases. ${ }^{1}$ TGF $\beta$ regulates target gene expression through SMAD-dependent and SMAD-independent pathways. Several TGF $\beta$ signaling mediators are altered during ovarian cancer development including ecotropic viral integration site-1 (EVI1), ${ }^{2,3}$ SnoN/SkiL, ${ }^{4}$ and TGF $\beta$ RII, and $\mathrm{PI} 3 \mathrm{~K} / \mathrm{AKT} .^{1,3}$ In ovarian cancers, suggested mechanisms for resistance to TGF $\beta$-mediated growth inhibition include decreased expression of TGF $\beta$ receptors, repression by oncoproteins (EVI1 and SnoN), dysregulation of RUNX1 activation, and activation of additional pathways such as PKC. ${ }^{1}$

Arsenic trioxide $\left(\mathrm{As}_{2} \mathrm{O}_{3}\right)$, used in patients with acute promyelocytic leukemia (APL), ${ }^{5}$ is active in vitro in several solid tumor cell lines, including ovarian cancer cells. ${ }^{6-8}$

\footnotetext{
${ }^{1}$ Department of Cell Biology, Microbiology, and Molecular Biology, University of South Florida, 4202 East Fowler Avenue, BSF218, Tampa, FL, USA; ${ }^{2}$ Department of Integrative Biology, University of South Florida, 4202 East Fowler Avenue, Tampa, FL, USA and ${ }^{3}$ MD Anderson Cancer Center, Department of Systems Biology, University of Texas, 1515 Holcombe Boulevard, Box 950, Houston, TX, USA

${ }^{*}$ Corresponding author: M Nanjundan, Department of Cell Biology, Microbiology, and Molecular Biology, University of South Florida, 4202 East Fowler Avenue, BSF218, Tampa, FL, 33620, USA. Tel: 813974 8133; Fax: 813974 1614; E-mail: mnanjund@ usf.edu

Keywords: ovarian cancer; ecotropic viral integration site-1 (EVI1); SnoN/SkiL; transforming growth factor- $\beta$ (TGF $\beta)$; arsenic trioxide $\left(\mathrm{As}_{2} \mathrm{O}_{3}\right)$; autophagy

Abbreviations: 3-MA, 3-methyladenine; APL, acute promyelocytic leukemia; $\mathrm{As}_{2} \mathrm{O}_{3}$, arsenic trioxide; ATG, autophagy-related genes; $\mathrm{BAF}$, bafilomycin $\mathrm{A1}$; DAPI, 4',6diamidino-2-phenylindole; DMSO, dimethyl sulfoxide; EBSS, Earle's balanced salt solution; EGFP, enhanced green fluorescent protein; EMT, epithelial-mesenchymal transition; EVI1, ecotropic viral integration site-1; FBS, fetal bovine serum; FITC, fluorescein isothiocyanate; GAPDH, glyceraldehyde-3-phosphate dehydrogenase; GSH, glutathione; hTERT, human telomerase reverse transcriptase; hVps34, human vacuolar protein sorting 34; LC3, light chain 3; MDS1, myelodysplastic syndrome 1; MRP1, multidrug resistance protein 1; NAC, N-acetyl-L-cysteine; PARP, poly (ADP-ribose) polymerase; PBS, phosphate-buffered saline; PI, propidium iodide; PI3K/ AKT, phosphatidylinositol-3-kinase/protein kinase B; PKC, protein kinase C; qPCR, quantitative/real-time PCR; ROS, reactive oxygen species; RUNX1, runt-related transcription factor 1; siRNA, small inhibitory RNA; SMAD, mothers against DPP homolog; SMURF2, SMAD-specific E3 ubiquitin ligase 2; SnoN, ski-related novel protein N; TAK1, transforming growth factor $\beta$-activating kinase 1; TBST, tris-buffered saline containing Tween-20; TEM, transmission electron microscopy; TGF $\beta$, transforming growth factor $\beta$; TGF $\beta$ RII, transforming growth factor $\beta$ receptor II; TRAIL, tumor necrosis factor-related apoptosis-inducing ligand

Received 20.8.09; revised 06.4.10; accepted 15.4.10; Edited by M Piacentini; published online 28.5.10
} 
In human ovarian carcinoma cell lines, $\mathrm{As}_{2} \mathrm{O}_{3}$ is highly cytotoxic, inducing apoptosis, necrosis, autophagy, and inhibiting invasion. ${ }^{6,8,9}$ The mechanism of action of $\mathrm{As}_{2} \mathrm{O}_{3}$ is unclear. Interestingly, in primary murine leukemia cells, $2-10 \mu \mathrm{M} \mathrm{As}_{2} \mathrm{O}_{3}$ is involved in proteasome degradation of EVI1, a well-known TGF $\beta$ signaling repressor. ${ }^{10}$ To analyze the mechanism of drug-induced cell death, we examined the effects of $\mathrm{As}_{2} \mathrm{O}_{3}$ on TGF $\beta$ signaling mediators in ovarian cells. $\mathrm{As}_{2} \mathrm{O}_{3}$ markedly altered protein levels of EVI1, SnoN, TGF $\beta$ RII, as well as other key TGF $\beta$ signaling mediators, including SMAD2/3 and AKT. EVI1 protein expression was restored by MG132/PS-341 treatment suggesting that $\mathrm{As}_{2} \mathrm{O}_{3}$ induced effects on EVI1 is regulated through the proteasome degradation pathway. $\mathrm{As}_{2} \mathrm{O}_{3}$ elicited a marked functional effect on cell growth and apoptosis in a number of ovarian cell lines, which correlated with multidrug resistance protein 1 (MRP1) protein expression. siRNA targeting ATG5, ATG7, and hVps34 markedly reduced autophagy in $\mathrm{As}_{2} \mathrm{O}_{3}$-treated ovarian carcinoma cells in contrast to beclin-1 knockdown, which had no effect implicating a beclin-1-independent mechanism in $\mathrm{As}_{2} \mathrm{O}_{3}$-induced autophagy. Moreover, SnoN altered cellular sensitivity to apoptosis by modulating LC3-II levels. Our results implicate SnoN as a potential target for therapy because it promotes cell survival through modulation of autophagy and apoptosis.

\section{Results}

$\mathrm{As}_{2} \mathrm{O}_{3}$ alters expression of TGF $\beta$ signaling mediators in ovarian cancer cells. To determine the mechanism of action of $\mathrm{As}_{2} \mathrm{O}_{3}$ in ovarian cancer cell lines, we initially determined its effect on the expression of TGF $\beta$ signaling mediators including EVI1, which is amplified at $3 q 26.2$ in ovarian cancers. ${ }^{2}$ We treated HEY and OVCA429 cells (highEVI1 expressing cell lines) for $18 \mathrm{~h}$ with increasing doses of $\mathrm{As}_{2} \mathrm{O}_{3}$ (Figure 1a and Supplementary Figure 1a). $\mathrm{As}_{2} \mathrm{O}_{3}$ markedly decreased protein levels of several EVI1 forms in both cell lines including MDS1/EVI1 (which consists of sequences derived from both EVI1 and the MDS1 gene, located telomeric to EVI1), ${ }^{11}$ full-length EVI1, and EVI1 ${ }^{\text {Del190-515 }}$ (similar to the identified $\Delta 324$ isoform isolated from human endometrial carcinoma cells). ${ }^{12,13}$ In contrast, $\mathrm{As}_{2} \mathrm{O}_{3}$ significantly increased SnoN/SkiL levels, also amplified at the 3q26.2 locus in ovarian cancers. ${ }^{4}$ Other TGF $\beta$ mediators markedly reduced by $\mathrm{As}_{2} \mathrm{O}_{3}$ treatment include (1) $\operatorname{TGF} \beta$ activating kinase 1 (TAK1), which phosphorylates SnoN targeting it for degradation, ${ }^{14}$ (2) SMAD2/3, (3) TGF $\beta$ RII, which is downregulated in advanced stage ovarian carcinomas relative to normal epithelium ${ }^{3}$ (western analysis shows multiple bands likely reflecting heterogeneity of the receptor), and (4) AKT, which can signal through the $\operatorname{TGF} \beta$ pathway by binding to SMAD3. ${ }^{15}$ Thus, these data show that $\mathrm{As}_{2} \mathrm{O}_{3}$ markedly alters expression of key TGF $\beta$ signaling mediators in ovarian cancer cells.

\footnotetext{
$\mathrm{As}_{2} \mathrm{O}_{3}$ induces the degradation of TGF $\beta$ signaling mediators through proteasome-dependent and -independent pathways. To determine whether alterations in expression of TGF $\beta$ signaling mediators after treatment with
}

$\mathrm{As}_{2} \mathrm{O}_{3}$ were due to proteasome-mediated degradation, we performed combinatorial studies with the proteasome inhibitor MG132. We used $\mathrm{As}_{2} \mathrm{O}_{3}$ at $5 \mu \mathrm{M}$ with $5 \mu \mathrm{M}$ MG132, which elicited minimal cellular toxicity compared with higher doses. The response of HEY and OVCA429 to these drug combinations were similar (Figure $1 \mathrm{~b}$ and Supplementary Figure 1b). Both EVI1 and EVI1 ${ }^{\text {Del190-515 }}$ protein expression were reduced with $5 \mu \mathrm{M} \mathrm{As} \mathrm{O}_{3}$ whereas there was little effect on MDS1/EVI1 (Figure 1b). ${ }^{10}$ The reduction of $\mathrm{EVI1}$ and $\mathrm{EVI1}{ }^{\text {Del190-515 }}$ expression with $\mathrm{As}_{2} \mathrm{O}_{3}$ was recovered with $M G 132$, suggesting that $\mathrm{As}_{2} \mathrm{O}_{3}$ induces the degradation of certain EVI1 forms through a proteasomemediated pathway. In contrast, TGF $\beta$ RII was not markedly recovered after 6 or $18 \mathrm{~h}$ treatment with MG132, suggesting that $\mathrm{As}_{2} \mathrm{O}_{3}$-induced degradation of TGF $\beta$ RII likely occurs through a proteasome-independent pathway. Strikingly, SnoN levels were further increased with MG132, suggesting that SnoN protein can be further stabilized through a proteasomemediated pathway. Similar effects were observed with PS-341 (Bortezomid/Velcade), another proteasome inhibitor (Figure 1c).

SMURF2 (E3 ubiquitin ligase) is involved in geldanamycininduced TGF $\beta$ RII degradation. ${ }^{16}$ However, treatment of OVCA429 and HEY ovarian cancer cells with SMURF2 siRNA (>90\% reduction in SMURF2 protein) did not significantly alter EVI1, SnoN, or TGF $\beta$ RII protein in the presence of $\mathrm{As}_{2} \mathrm{O}_{3}$ (Supplementary Figure 1c) suggesting other E3 ubiquitin ligases are involved in $\mathrm{As}_{2} \mathrm{O}_{3}$-induced degradation of TGF $\beta$ RII, SnoN, or EVI1.

We next assessed whether $\mathrm{As}_{2} \mathrm{O}_{3}$-induced alterations in AKT, SMAD2/3, and TGF $\beta$ RII protein with MG132 were due to changes in (1) protein expression independent of the proteasome or (2) RNA levels. MG132 treatment at $18 \mathrm{~h}$ not only significantly decreased their protein levels (Figure 1d and Supplementary Figure 1d), but markedly reduced EVI1 and TGF $\beta$ RII RNA levels (Figure $1 \mathrm{e}$ and Supplementary Figure 1e). We also examined the effect of $\mathrm{As}_{2} \mathrm{O}_{3}$ on RNA levels (Figure 1e) because $\mathrm{As}_{2} \mathrm{O}_{3}$ can alter RNA expression such as survivin. ${ }^{17,18}$ However, we observed $<20 \%$ decrease in EVI1 and TGF $\beta$ RII RNA levels with little effect on SnoN RNA. Collectively, these results suggest that $\mathrm{As}_{2} \mathrm{O}_{3}$-induced expression changes occur mostly at the protein level.

Decreased sensitivity to $\mathrm{As}_{2} \mathrm{O}_{3}$-induced cell death in ovarian cells expressing high MRP1 protein. To examine the functional effects of $\mathrm{As}_{2} \mathrm{O}_{3}$ on both normal and ovarian cancer cells, we assessed its effects on cell growth in (1) T80, a large T antigen/hTERT immortalized normal ovarian surface epithelial cell line (low-expressing EVI1 cell line), (2) HEY (moderate-expressing EVI1 cell line), and (3) SKOV3, (high-expressing EVI1 cell line). ${ }^{2}$ We previously reported the expression profile of EVI1 in these ovarian cells. $^{2}$ High-expressing EVI1 cells (HEY and SKOV3) were more resistant to effects of $\mathrm{As}_{2} \mathrm{O}_{3}$ compared with low-EVI1 expressing cells (T80) based on cell viability assays (Figure 2a). On microscopic examination, we observed that these cells developed numerous cytoplasmic vacuoles and were apoptotic as evidenced by apoptotic morphology and substratum release (Figure 2b). Staining with annexin 
a

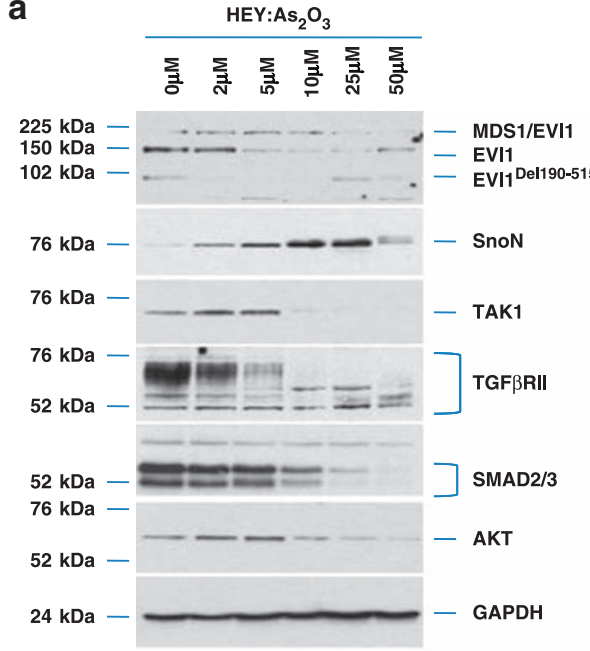

C

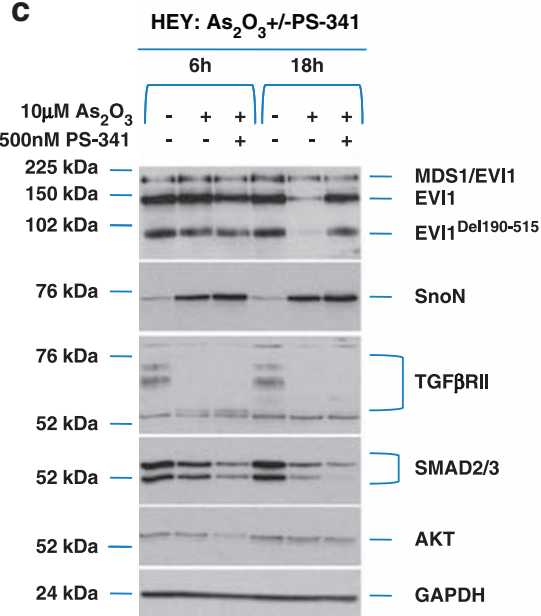

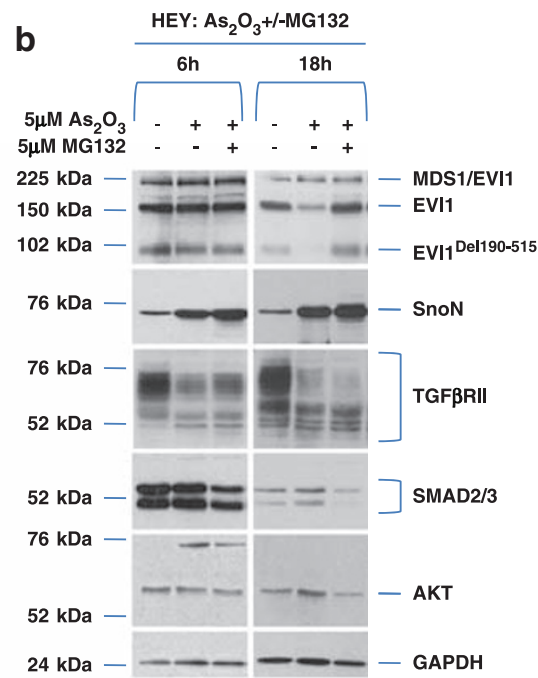
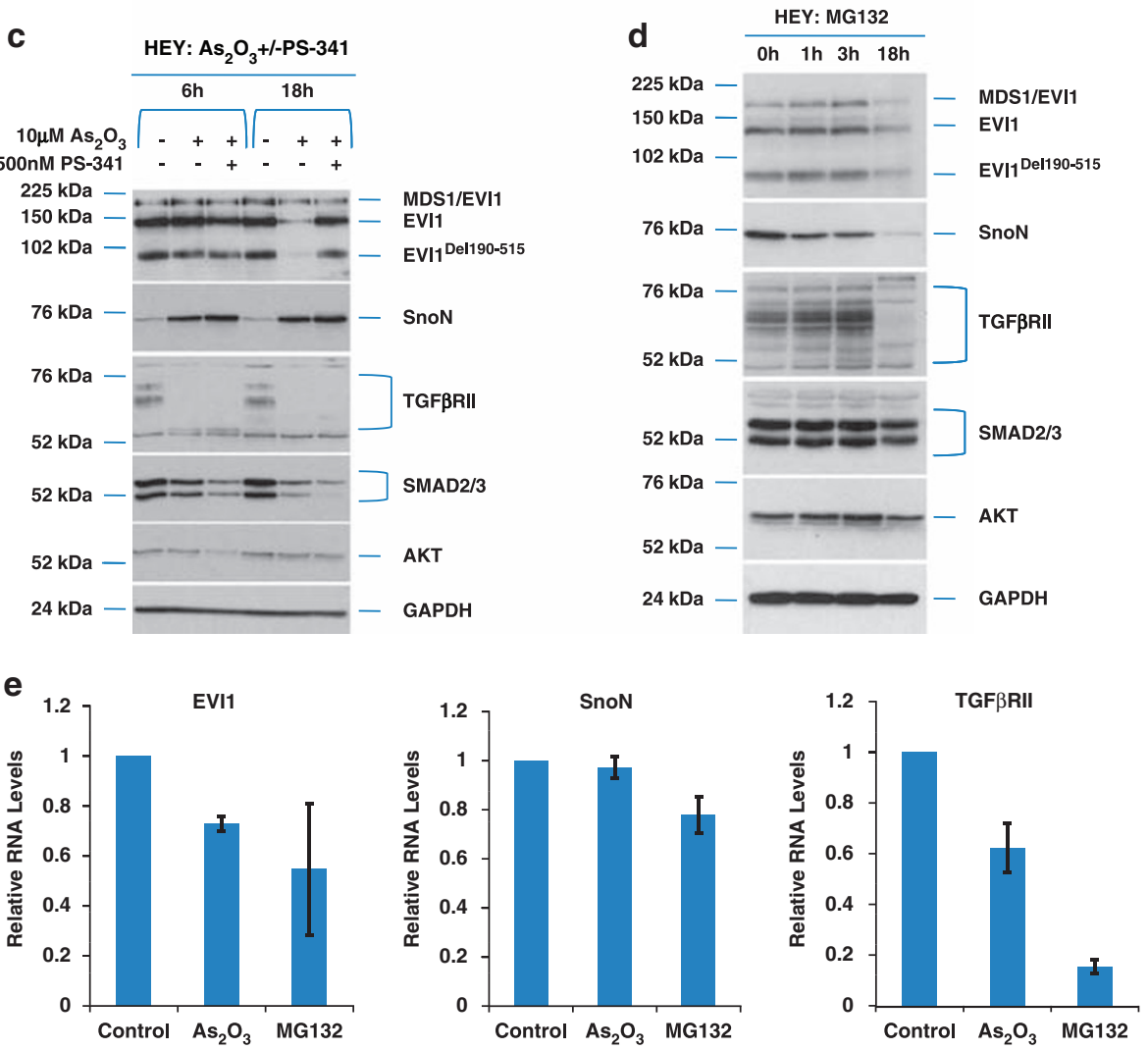

Figure $1 \quad \mathrm{As}_{2} \mathrm{O}_{3}$ alters expression of TGF $\beta$ signaling mediators in $\mathrm{HEY}$ ovarian cancer cell line. (a) HEY cells were seeded at 250000 cells per well in six-well plates. After overnight attachment, the cells were treated with varying concentrations of $\mathrm{As}_{2} \mathrm{O}_{3}(2-50 \mu \mathrm{M})$. After $18 \mathrm{~h}$ incubation, the cell lysates were harvested and western analysis was performed using the following antibodies: (1) EVI1, (2) SnoN, (3) TAK1, (4) TGF $\beta R I I$, (5) SMAD2/3, (6) AKT, and (7) GAPDH as a loading control. The data shown are representative of four independent experiments. (b) $\mathrm{HEY}$ cells were seeded at 250000 cells per well in six-well plates. After overnight attachment, the cells were treated with (1) $5 \mu \mathrm{M} \mathrm{As} \mathrm{O}_{3}$, (2) $5 \mu \mathrm{M} \mathrm{MG} 132$, or (3) $5 \mu \mathrm{M} \mathrm{As}_{2} \mathrm{O}_{3}$ and $5 \mu \mathrm{M} \mathrm{MG132}$. After 6 or $18 \mathrm{~h}$ treatment, the cell lysates were harvested and western analysis was performed using the following antibodies: (1) EVI1, (2) SnoN, (3) TGF $\beta$ RII, (4) SMAD2/3, (5) AKT, and (6) GAPDH as a loading control. The data shown are representative of three independent experiments. (c) HEY cells were seeded at 250000 cells in six-well plates. After overnight attachment, the cells were treated with (1) $10 \mu \mathrm{M} \mathrm{As}_{2} \mathrm{O}_{3}$, (2) $500 \mathrm{nM} \mathrm{PS}-341$, or (3) $10 \mu \mathrm{M} \mathrm{As} \mathrm{O}_{3}$ and $500 \mathrm{nM}$ PS-341. After 6 or $18 \mathrm{~h}$ treatment, the cell lysates were harvested and western analysis was performed using the following antibodies: (1) EVI1, (2) SnoN, (3) TGF $\beta$ RII, (4) SMAD2/3, (5) AKT, and (6) GAPDH as a loading control. The data shown are representative of three independent experiments. (d) HEY cells were seeded at 250000 cells per well in six-well plates. After $24 \mathrm{~h}$, the cells were treated at different time points $(1,3$, and $18 \mathrm{~h})$ with $5 \mu \mathrm{M} \mathrm{MG} 132$. Cell lysates were harvested and western analysis was performed using the following antibodies: (1) EVI1, (2) SnoN, (3) TGF $\beta$ RIII, (4) SMAD2/3, (5) AKT, and (6) GAPDH as a loading control. The data shown are representative of three independent experiments. (e) $\mathrm{HEY}$ cells were seeded at 500000 cells per well in six-well plates. After $24 \mathrm{~h}$, the cells were treated with (1) DMSO, (2) $5 \mu \mathrm{M} \mathrm{As} \mathrm{O}_{3}$ and DMSO, or (3) $5 \mu \mathrm{M}$ MG132 for $18 \mathrm{~h}$. RNA was then isolated and used for qPCR. Relative RNA-fold changes are presented for EVI1, SnoN, and TGF $\beta$ RII. The data shown are representative of three independent experiments 
V-FITC and propidium iodide (PI) to quantify changes in apoptosis indicated that, after $\mathrm{As}_{2} \mathrm{O}_{3}$ treatment, normal ovarian cells (T80) had a markedly higher apoptotic percentage $(>80 \%)$ compared with ovarian cancer cells (SKOV3 and HEY; <20\%) (Figure 2c). These results indicate that normal ovarian cells (T80) are more sensitive to $\mathrm{As}_{2} \mathrm{O}_{3}-$ induced apoptosis compared with cancer cells (HEY and SKOV3). In contrast, $\mathrm{As}_{2} \mathrm{O}_{3}$ reduced the migratory potential
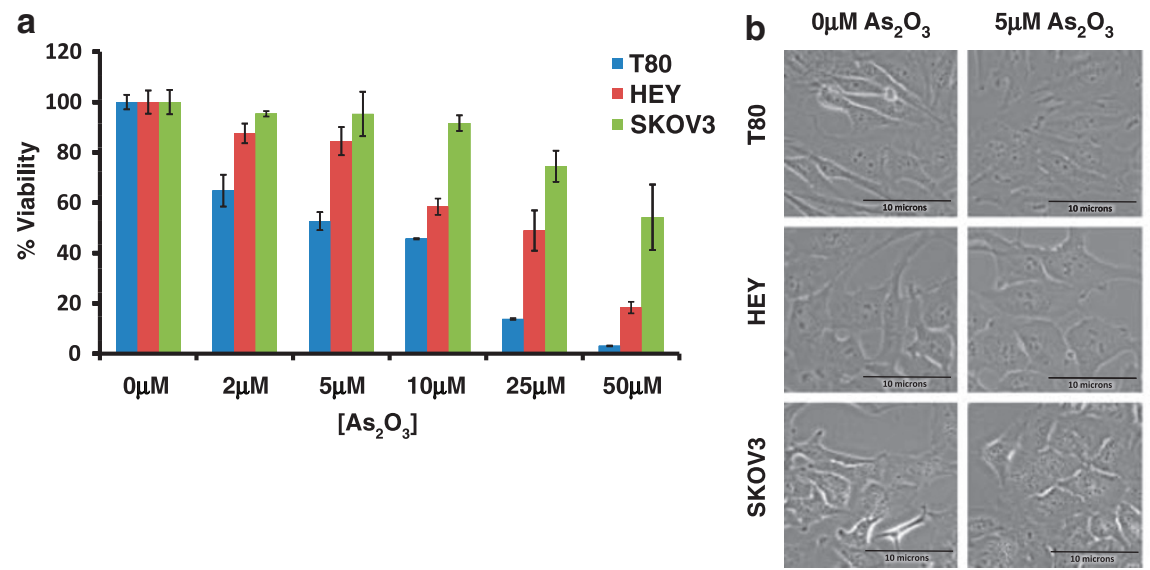

C

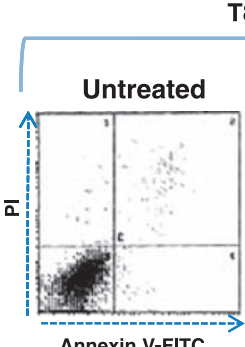

Annexin V-FITC

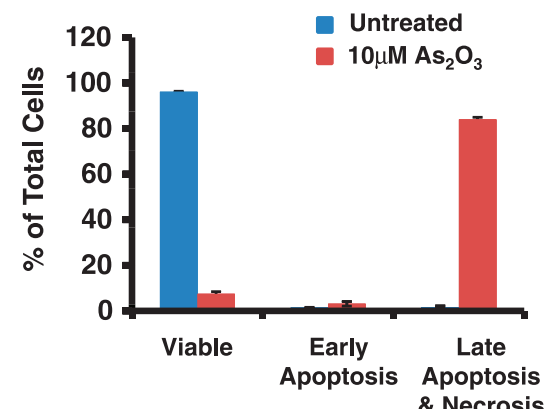

d

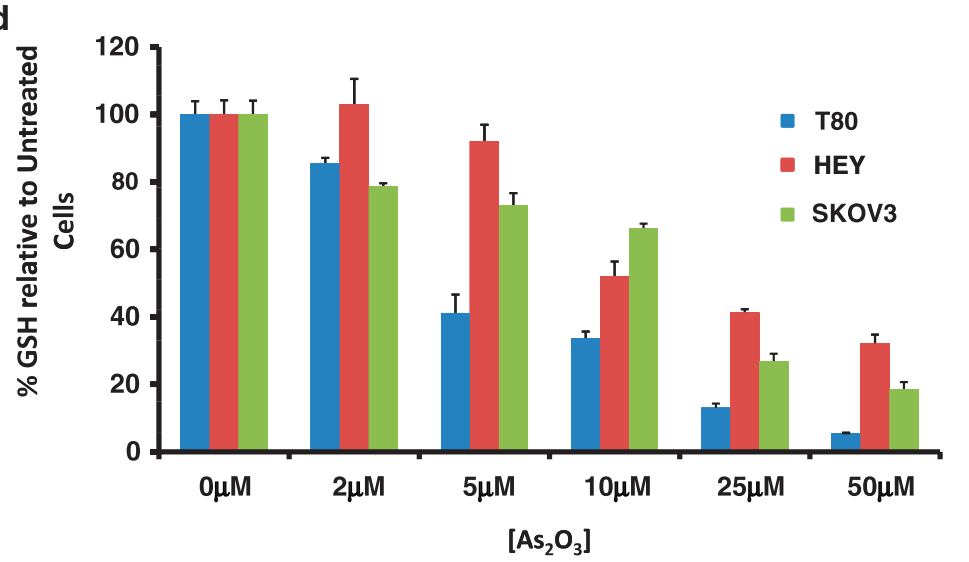

HEY
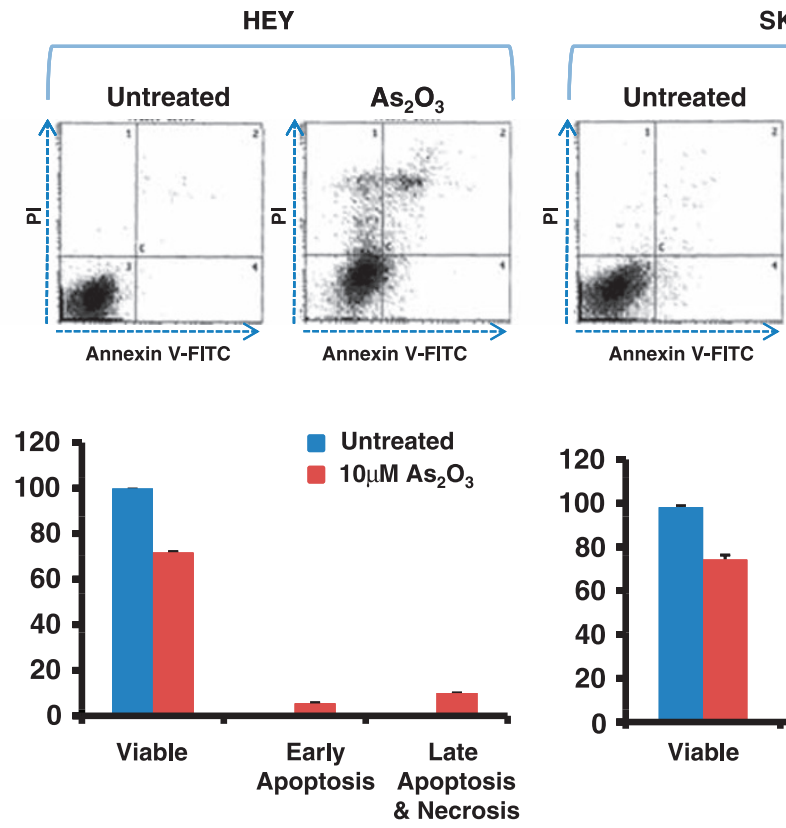

Annexin V-FITC

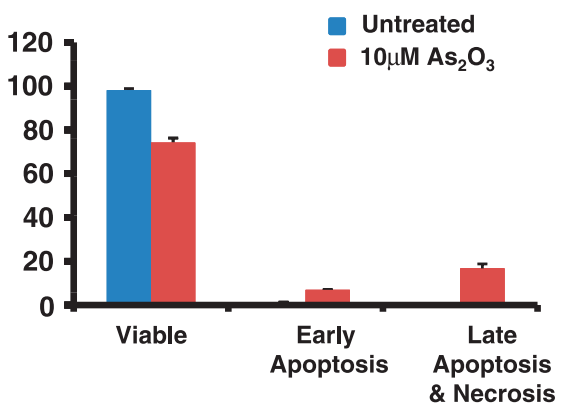

e

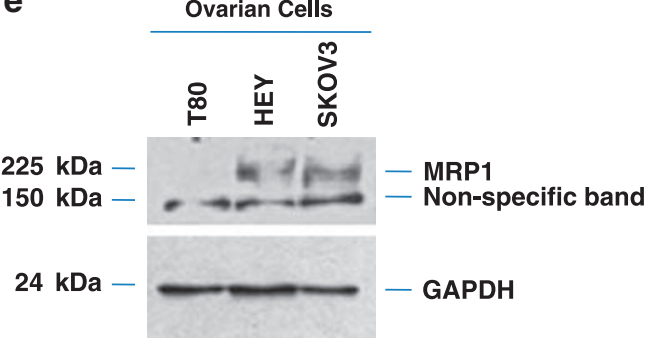


of both normal and cancer cell lines similarly by $>50 \%$ (Supplementary Figure 2).

As $\mathrm{As}_{2} \mathrm{O}_{3}$ has been reported to reduce intracellular glutathione (GSH) levels, ${ }^{19}$ we next assessed whether $\mathrm{GSH}$ levels in T80, HEY, and SKOV3 cells may be correlated with the sensitivity to $\mathrm{As}_{2} \mathrm{O}_{3}$. All cell lines had reduced $\mathrm{GSH}$ levels after $\mathrm{As}_{2} \mathrm{O}_{3}$ treatment with markedly reduced levels in normal immortalized ovarian T80 cells compared with HEY and SKOV3 (Figure 2d). As GSH can bind to trivalent arsenic and is effluxed out of cells through MRP $1,{ }^{20}$ we thus analyzed the level of MRP1 protein in these ovarian cell lines. Indeed, we found that MRP1 was highly expressed in SKOV3 and HEY cells (highly resistant to $\mathrm{As}_{2} \mathrm{O}_{3}$-mediated effects) and low in T80 cells (Figure $2 \mathrm{e}$ ). Together, these results suggest that the decreased sensitivity to $\mathrm{As}_{2} \mathrm{O}_{3}$ in ovarian carcinoma cells may be due to increased efflux of $\mathrm{GSH}-\mathrm{As}_{2} \mathrm{O}_{3}$ through MRP1.

$\mathrm{As}_{2} \mathrm{O}_{3}$ induces formation of autophagosomes. As formation of cytoplasmic vacuoles with $\mathrm{As}_{2} \mathrm{O}_{3}$ treatment was suggestive of induction of autophagy (see Figure $2 b$ ), we first examined protein expression of microtubule-associated protein light chain 3 (LC3), a marker of autophagic vesicle formation. $\mathrm{As}_{2} \mathrm{O}_{3}$ increased levels of both the LC3-I (cytosolic form, $18 \mathrm{kDa}$ ) and LC3-II (membrane-bound form, $16 \mathrm{kDa}$ ), which correlated with SnoN expression at 10-25 $\mu \mathrm{M}$ in T80/ HEY cells and $>25 \mu \mathrm{M}$ in SKOV3 cells (Figure 3a). p62/ SQSTM1, which recruits autophagic machinery to inclusion bodies as a protective response for clearing protein aggregates through the autophagic pathway, ${ }^{21}$ also increased in a dose-dependent manner. In addition, poly (ADP-ribose) polymerase $(116 \mathrm{kDa}, \mathrm{PARP})$, which is proteolytically fragmented to 89 and $24 \mathrm{kDa}$ (early marker of apoptosis) by caspase-3, which precedes DNA fragmentation, dramatically increased at a dose of $25 \mu \mathrm{M}$ (T80) and $50 \mu \mathrm{M}$ (HEY and SKOV3) correlating with the apoptotic sensitivity determined by Annexin $\mathrm{V}$ staining (see Figure 2c).

As the development of cytoplasmic vacuoles at $18 \mathrm{~h}$ treatment preceded apoptosis as determined by light microscopy (Figure $3 b$ ), we performed a kinetic profile to follow these events in a time-dependent manner with respect to expression of TGF $\beta$ mediators (Figure 3c). We observed induction of $\mathrm{SnoN}$ at $9 \mathrm{~h} \mathrm{As}_{2} \mathrm{O}_{3}$ treatment, which correlated with changes in LC3-II and p62. We observed dramatic decreases in EVI1, TAK1, SMAD2/3, and TGF $\beta$ RII expression levels at $18 \mathrm{~h}$ treatment, which correlated with marked increases in the LC3-I/II ratio as well as reduction in procaspase-3 and increased cleaved PARP. Induction of another potential splice variant of EVI1 ( 60 kDa, detected using an antibody, which detects multiple splice forms of EVI1) followed levels of cleaved PARP. These results provide evidence for the correlation of the induction of expression of SnoN with the autophagic marker, LC3-II, which precedes changes in apoptotic markers. Interestingly, beclin-1 levels did not increase but decreased after $18 \mathrm{~h}$ treatment.

We next identified the presence of autophagosomes by transmission electron microscopy (TEM). By TEM, we positively identified the presence of numerous doublemembrane autophagosomes with $\mathrm{As}_{2} \mathrm{O}_{3}$ treatment (Figures $3 \mathrm{~d}$ and e). After $3 \mathrm{~h} \mathrm{As}_{2} \mathrm{O}_{3}$ treatment, formation of double-membrane structures was observed. At $9 \mathrm{~h}$, autophagosomes were fully formed and at $18 \mathrm{~h}$, clearing within autophagosomes was observed suggesting degradation of the cytoplasmic contents (Figure $3 \mathrm{e}$ ). Beyond $18 \mathrm{~h}$, the cells underwent apoptosis (results not shown). In addition, we transfected EGFP-LC3 cDNA into HEY cells to identify fluorescent vacuoles after $\mathrm{As}_{2} \mathrm{O}_{3}$ treatment and observed a punctate staining pattern around the nucleus with $5 \mu \mathrm{M}$ to $25 \mu \mathrm{M} \mathrm{As}{ }_{2} \mathrm{O}_{3}$ compared with diffuse EGFP fluorescence in untreated cells $\left(0 \mu \mathrm{M} \quad \mathrm{As}_{2} \mathrm{O}_{3}\right)$ (see Figures $5 \mathrm{a}$ and b). Collectively, these results show that $\mathrm{As}_{2} \mathrm{O}_{3}$ induces the development of autophagosomes in parallel with induction of SnoN protein, which precedes changes in apoptotic markers.

\section{$\mathrm{As}_{2} \mathrm{O}_{3}$ mediates its effects in ovarian cells through the generation of reactive oxygen species (ROS). To determine whether the $\mathrm{As}_{2} \mathrm{O}_{3}$-induced changes observed in expression of TGF $\beta$ signaling mediators are due to the effects of oxidative stress, we treated HEY cells with $\mathrm{As}_{2} \mathrm{O}_{3}$ in combination with the antioxidant $\mathrm{N}$-acetyl-L-cysteine (NAC), a free radical scavenger/reducing agent and GSH precursor, which protects against $\mathrm{As}_{2} \mathrm{O}_{3}$-induced apoptosis in tumor cells. ${ }^{22}$ Light micrographs of cells co-treated with $10 \mu \mathrm{M} \mathrm{As} \mathrm{As}_{2} \mathrm{O}_{3}$ and $1000 \mu \mathrm{M}$ NAC showed a dramatic reduction in cytoplasmic vacuolation and apoptotic morphology in contrast to cells treated with $10 \mu \mathrm{M} \mathrm{As} \mathrm{O}_{3}$ alone (Figure 4a). Further, increasing doses of NAC markedly reduced SnoN with a corresponding recovery in EVI1 and TGF $\beta$ RII proteins (Figure 4b, left panel). The results indicate that TGF $\beta$ signaling mediator expression can be altered by the presence of ROS. Although the levels of p62 remained unchanged or increased slightly, there was a reduction in LC3-I levels (Figure 4b, right panel). Further, we observed a dramatic reduction in punctate EGFP-LC3 staining suggesting $\mathrm{As}_{2} \mathrm{O}_{3}$-induced autophagy can be}

Figure $2 \mathrm{As}_{2} \mathrm{O}_{3}$ induces cell death. (a) Cell viability was assessed using the CellTiter-Glo assay in T80, $\mathrm{HEY}$, and $\mathrm{SKOV}_{3}$ cells treated for $18 \mathrm{~h}$ with varying doses of $\mathrm{As}_{2} \mathrm{O}_{3}$ $(2-50 \mu \mathrm{M})$. Results are presented as \% cell viability relative to control cells $(0 \mu \mathrm{M})$. The data shown are representative of three independent experiments. (b) T80, HEY, and SKOV 3 cells were seeded at 250000 cells per well. After $24 \mathrm{~h}$, the cells were treated with varying concentrations of $\mathrm{As}_{2} \mathrm{O}_{3}(5-50 \mu \mathrm{M})$. After $18 \mathrm{~h}$ treatment, images were captured at $\times 40$ magnification. The data shown are representative images. (c) HEY cells were seeded at 250000 cells per well in six-well plates. After cell attachment, cells were treated with $10 \mu \mathrm{M} \mathrm{As}_{2} \mathrm{O}_{3}$ at which time both the floating and adherent cells were collected. Cells were stained with annexin V-FITC and PI followed by flow cytometric analysis. (Top panels) raw data plots are shown as log fluorescence values of annexin V-FITC and PI on the $X$ and $Y$ axis, respectively. (Bottom panels) the data are shown in bar graphs as the percentage of viable, early apoptotic, and late apoptotic/necrotic cells. The data shown are representative of two independent experiments. (d) GSH levels were quantified in T80, HEY, and SKOV3 cells using the GSH-glo assay kit. Results are presented as \% GSH relative to untreated cells. The data shown are representative of three independent experiments. (e) T80, HEY, and SKOV3 cells were grown to confluence in T-25 flasks. Cell lysates were harvested into $200 \mu$ l of lysis buffer containing $10 \mathrm{mM}$ sodium orthovanadate, $100 \mathrm{mM}$ sodium fluoride, and protease cocktail inhibitors. Western analysis was performed using the following antibodies: (1) MRP1 and (2) GAPDH. The data are representative of two independent experiments 
a
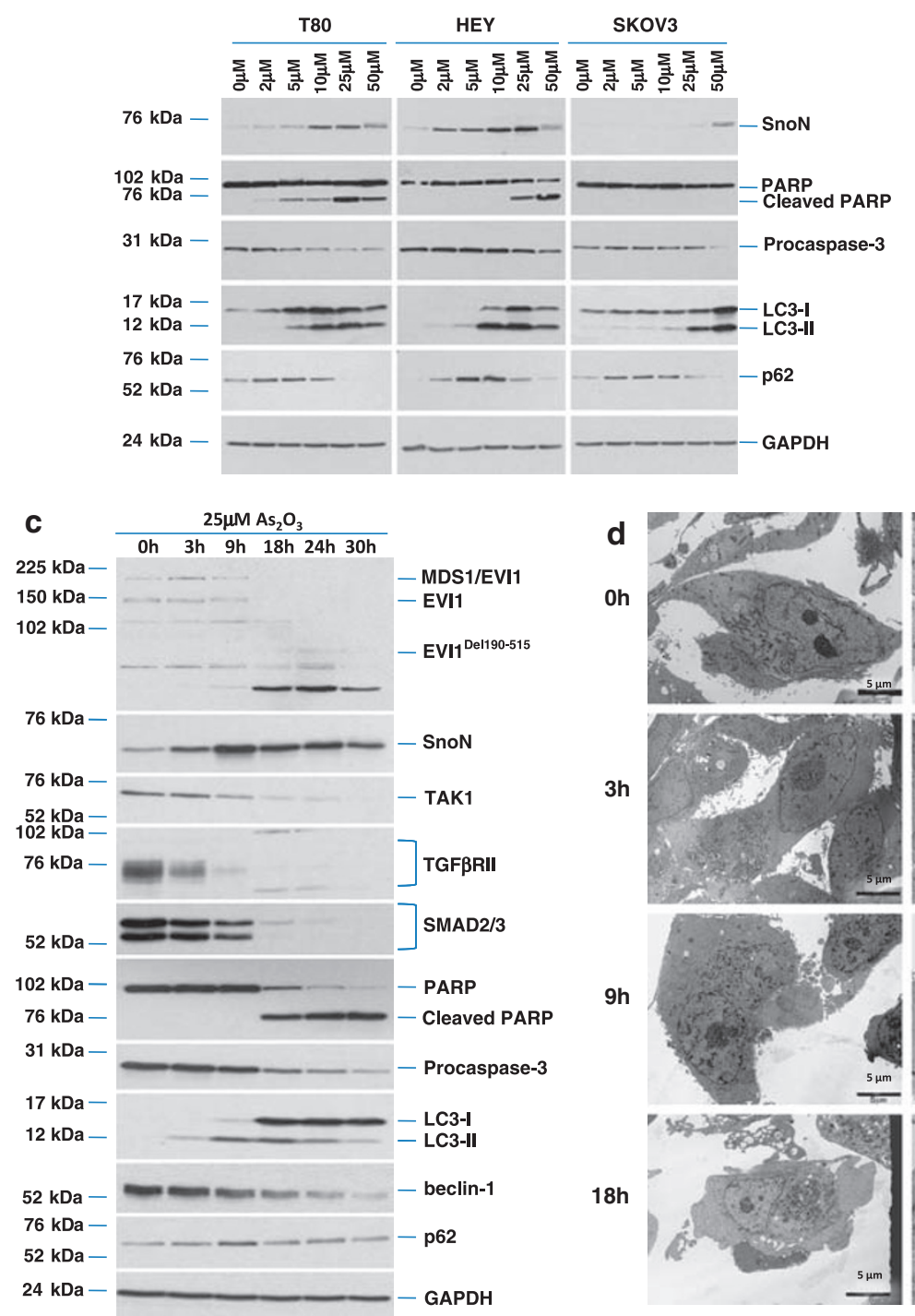

b

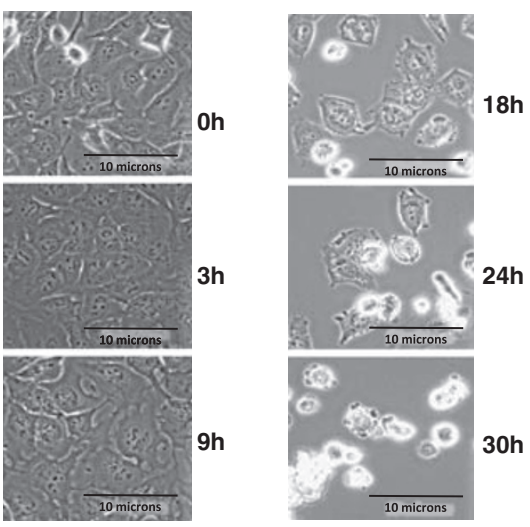

d

oh

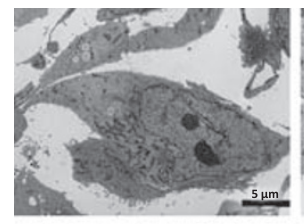

$3 h$
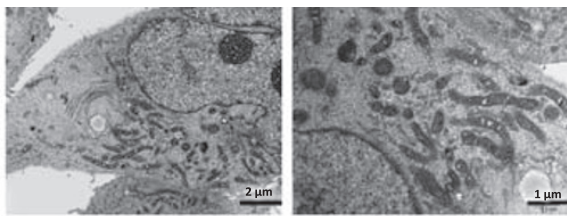

9h
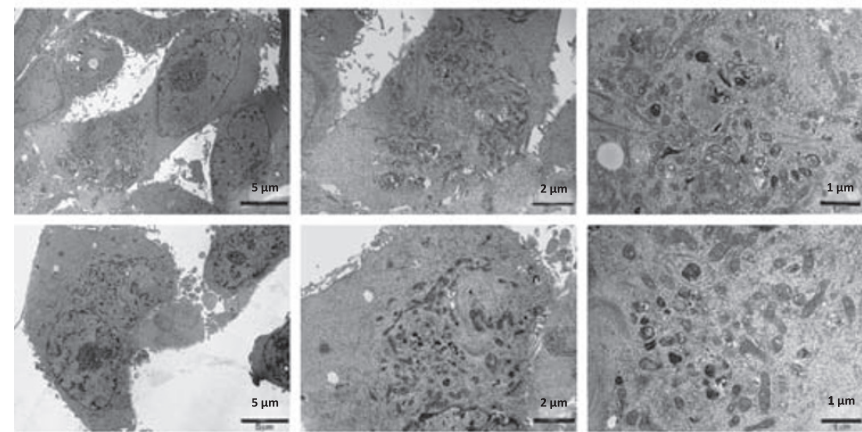

$18 \mathrm{~h}$
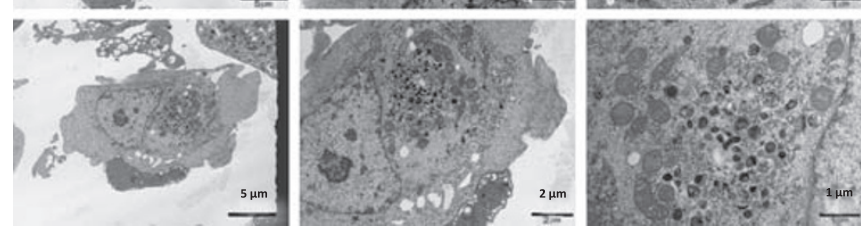

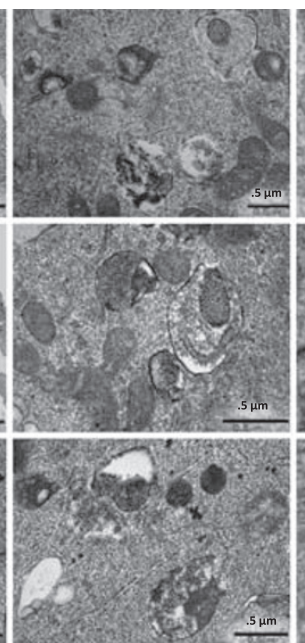

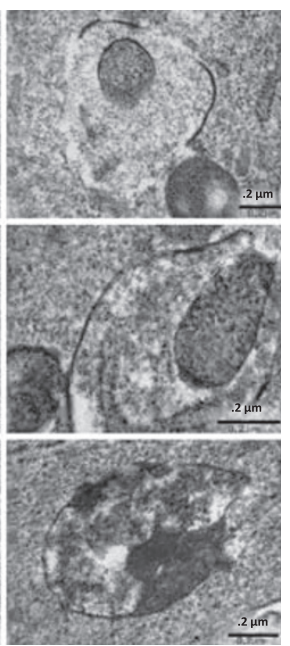


reversed by addition of antioxidant (Figure 4c, top and bottom panels). We observed an increase in cell survival after co-treatment with $10 \mu \mathrm{M} \mathrm{As} \mathrm{A}_{3}$ and $1000 \mu \mathrm{M}$ NAC (Figure 4d) indicating that NAC promotes increased cellular viability. As the level of cleaved PARP was difficult to detect at $10 \mu \mathrm{M} \mathrm{As} \mathrm{O}_{3}$ (Figure $4 \mathrm{~b}$, right panel), we quantified changes in apoptosis by staining with annexin V-FITC and $\mathrm{PI}$. We observed a significant decrease in apoptotic cells on co-treatment with $10 \mu \mathrm{M} \mathrm{As}_{2} \mathrm{O}_{3}$ and NAC compared with $\mathrm{As}_{2} \mathrm{O}_{3}$-only treated cells (Figure $4 \mathrm{e}$ ). Together, these results suggest that $\mathrm{As}_{2} \mathrm{O}_{3}$ mediates its effects through the generation of ROS, which alters the autophagic and apoptotic response.

$\mathrm{As}_{2} \mathrm{O}_{3}$ induces autophagy through a beclin-1independent pathway. To determine whether autophagy is a necessary step in induction of cell death through $\mathrm{As}_{2} \mathrm{O}_{3}$, we tested the effects of various inhibitors of autophagy and apoptosis. 3-Methyladenine (3-MA) is a class III phosphatidylinositol-3-kinase (PI3K) inhibitor that inhibits autophagy at the earliest stage of autophagosome formation and is associated with decreased LC3-II expression. ${ }^{23}$ Although SnoN levels were not dramatically altered in HEY cells co-treated with $\mathrm{As}_{2} \mathrm{O}_{3}$ and 3-MA, there was reduced formation of EGFP-LC3 punctae (Figures $5 a$ and b), decreased LC3 protein, and increased cleaved PARP (used as marker of apoptosis) in contrast to cells treated with $25 \mu \mathrm{M} \mathrm{As}_{2} \mathrm{O}_{3}$ alone (Figure $5 \mathrm{c}$ ). Although beclin-1 levels were previously reported to be suppressed by 3-MA treatment, ${ }^{24}$ we did not detect any marked changes in beclin-1 levels in HEY cells co-treated with 3-MA and $\mathrm{As}_{2} \mathrm{O}_{3}$ (Figure 5c). Moreover, addition of 3-MA to resveratrol-treated ovarian cells failed to elicit a marked change in beclin-1 or LC3 expression (Supplementary Figures $3 a$ and b). In contrast, nutrient starvation with EBSS markedly increased both LC3 and beclin-1 levels, which were both reduced after treatment with 3-MA (Supplementary Figures $4 a$ and b). We next analyzed the effect of bafilomycin A1 (BAF), a late-stage autophagy inhibitor that hinders fusion of lysosomes to autophagosomes leading to inhibition of the degradation of inner contents and accumulation of uncleaved LC3-II protein. ${ }^{25}$ Western analysis of $\mathrm{HEY}$ cells co-treated with $\mathrm{As}_{2} \mathrm{O}_{3}$ and BAF showed increased LC3-II and cleaved PARP levels (Figure 5d, left panel). These results suggest that inhibition of late stage autophagy leads to increased apoptosis. Further, SnoN levels were slightly reduced with $\mathrm{BAF}$ in the presence of $\mathrm{As}_{2} \mathrm{O}_{3}$ suggesting a role for $\mathrm{SnoN}$ in this process. In addition, we analyzed the effect of zVAD-fmk, a caspase inhibitor, which inhibits apoptosis, to provide additional evidence that $\mathrm{As}_{2} \mathrm{O}_{3}$ - induced autophagy is independent of apoptosis. ${ }^{26}$ Although the levels of SnoN and LC3 remained unchanged with increasing concentrations of zVAD-fmk (Figure $5 \mathrm{~d}$, right panel), cleaved PARP was markedly reduced suggesting decreased apoptosis. Collectively, these results suggest that $\mathrm{As}_{2} \mathrm{O}_{3}$ induced autophagy confers a protective role against apoptosis, which is the primary cell death mechanism induced by $\mathrm{As}_{2} \mathrm{O}_{3}$.

As these inhibitors can induce nonspecific effects, we thus assessed knockdown of specific ATG genes on autophagy and apoptosis in HEY cells. Several key regulators of autophagy were detectable by western analysis in ovarian cells such as hVps34, beclin-1, ATG5, and ATG7 (Figure 5e). Although knockdown of beclin-1 by siRNA treatment for 2 consecutive days effectively (>95\%) reduced protein expression (Figure 5f), it did not affect expression of LC3-II/ LC3-I (Figure 5f) or significantly modulate formation of LC3 punctae induced by $\mathrm{As}_{2} \mathrm{O}_{3}$ (Figures $5 \mathrm{~g}$ and $\mathrm{h}$ ). In contrast, ATG5, ATG7, and hVps34 siRNA markedly altered the ratio of LC3-II/LC3-I (Figure 5f) and LC3 punctae formation (Figures $5 \mathrm{~g}$ and $\mathrm{h}$ ). Staining with annexin V-FITC and PI showed only subtle changes in the apoptotic response with ATG siRNAs (Figure 5i). Furthermore, we assessed beclin-1 knockdown with EBSS treatment, which led to reduced LC3-II levels (Supplementary Figure 4c). However, we could not accurately assess the effect of EBSS on LC3 punctae formation because of the dramatically altered cell morphology (i.e., cell rounding). Together, these results suggest that $\mathrm{As}_{2} \mathrm{O}_{3}$ elicits its effects on autophagy in a beclin-1-independent manner.

Modulation of the sensitivity of ovarian cancer cells to $\mathrm{As}_{2} \mathrm{O}_{3}$ by SnoN knockdown. As we observed that SnoN levels paralleled those of LC3, we analyzed whether SnoN could alter LC3-II levels and production of autophagosomes. Light microscopy suggests that knockdown of SnoN increases the sensitivity of the cells to $\mathrm{As}_{2} \mathrm{O}_{3}$ treatment leading to increased cell death compared with control siRNAtreated cells (Figure 6a). In SnoN knockdown cells (>90\% decrease in SnoN protein) treated with $\mathrm{As}_{2} \mathrm{O}_{3}$, western analysis showed a marked reduction in LC3-II and p62 levels with an increase in cleaved PARP compared with control siRNA cells treated with $25 \mu \mathrm{M} \mathrm{As} \mathrm{O}_{3}$ (Figure 6b). These protein changes corresponded with a reduction in EGFPLC3 punctae (Figure 6c), a marked reduction in cell survival (Figure $6 \mathrm{~d}$ ), and increased levels of apoptosis determined by annexin V-FITC and PI staining (Figure 6e). Thus, these data suggest that the sensitivity to $\mathrm{As}_{2} \mathrm{O}_{3}$-induced autophagy and apoptosis can be modulated by altering SnoN levels.

qPCR measurements of LC3 RNA transcripts indicated that its levels are low and SnoN siRNA did not modulate

\footnotetext{
Figure $3 \quad \mathrm{As}_{2} \mathrm{O}_{3}$ induces autophagy in ovarian cells. (a) T80 (left panel), HEY (middle panel), and SKOV3 (right panel) cells were seeded at 250000 cells per well in sixwell plates. After overnight attachment, the cells were treated with varying concentrations of $\mathrm{As}_{2} \mathrm{O}_{3}(2-50 \mu \mathrm{M})$. After $18 \mathrm{~h}$ incubation, the cell lysates were harvested and western analysis was performed using the following antibodies: (1) SnoN, (2) PARP, (3) procaspase-3, (4) LC3, (5) p62, and (6) GAPDH as a loading control. The data shown are representative of three independent experiments. (b) HEY cells were plated at 250000 cells per well in six-well plate. After overnight attachment, cells were treated with $25 \mu \mathrm{M} \mathrm{As} \mathrm{O}_{3}$ for varying times $(0,3,9,18,24$, and $30 \mathrm{~h})$ and light microscope images were captured at $\times 40$ magnification. The data shown are representative images. (c) HEY cells were seeded at 250000 cells per well. After overnight attachment, the cells were treated with $25 \mu \mathrm{M} \mathrm{As} \mathrm{O}_{3}$ at various time points $(3,9,18,24$, and $30 \mathrm{~h})$. Cell lysates were harvested and western analysis was performed using the following antibodies: (1) EVI1, (2) SnoN, (3) TAK1, (4) TGF $\beta R I I$, (5) SMAD2/3, (6) PARP, (7) procaspase-3, (8) LC3, (9) beclin-1, (10) p62, and (11) GAPDH as a loading control. The data shown are representative of two independent experiments. (d and e), confluent HEY cells grown in T-75 flasks were treated with $25 \mu \mathrm{M} \mathrm{As} \mathrm{O}_{3}$ for 3,9 , and $18 \mathrm{~h}$ and prepared for TEM. Images were captured at varying magnifications as indicated. Representative images are shown
} 
a
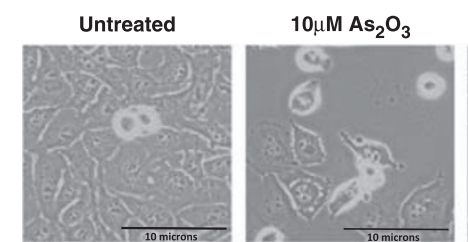

b

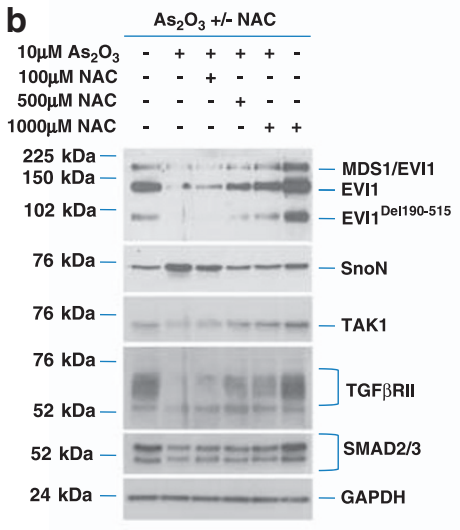

d

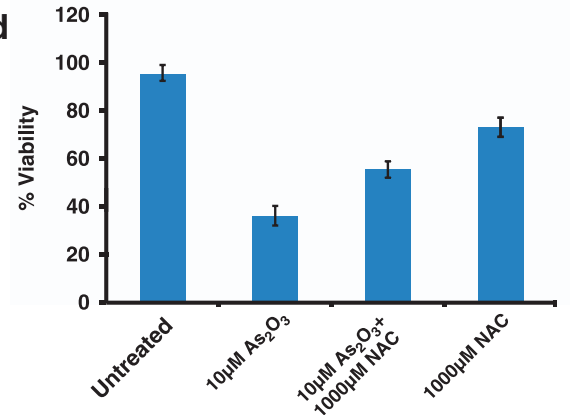

$10 \mu \mathrm{M} \mathrm{As} \mathrm{O}_{3}+$
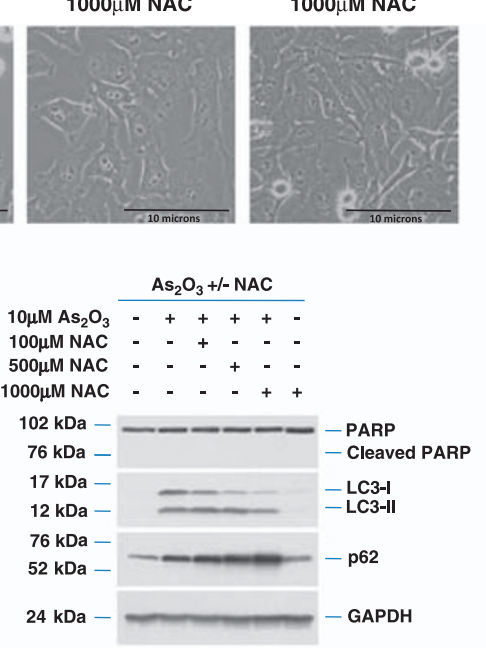
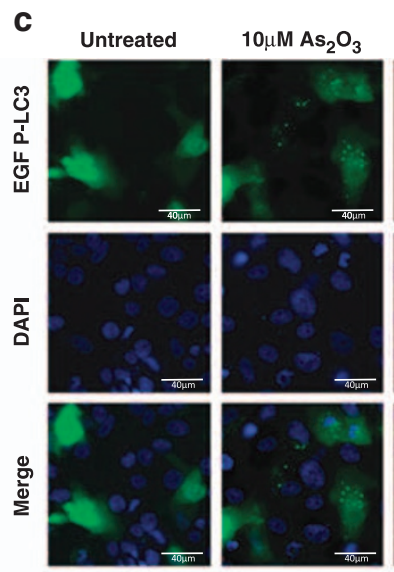

$10 \mu \mathrm{M} \mathrm{As} \mathrm{O}_{3}$ $1000 \mu \mathrm{M} N A C$

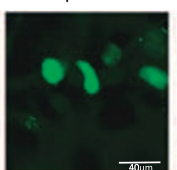

$1000 \mu \mathrm{M} N A C$
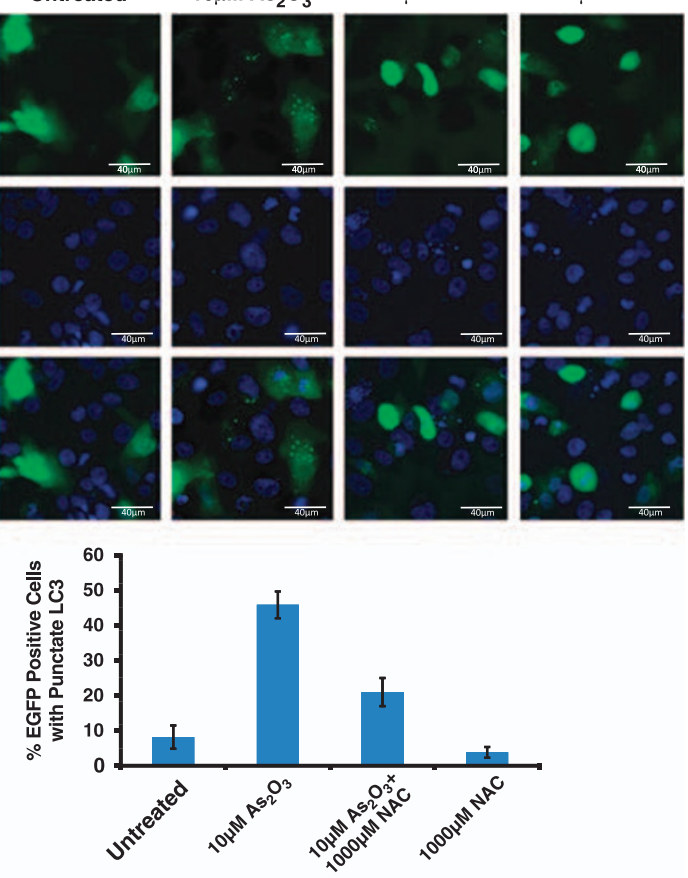

e

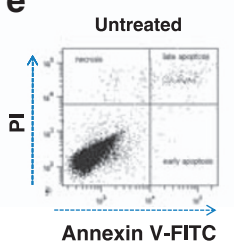

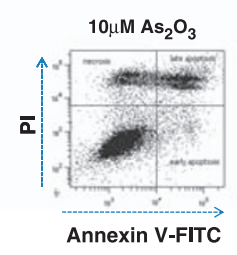
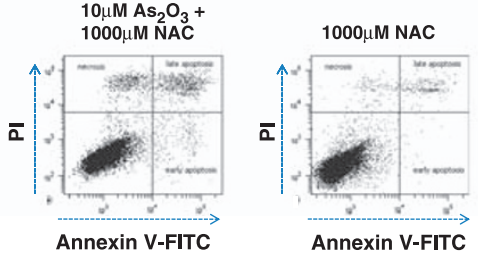

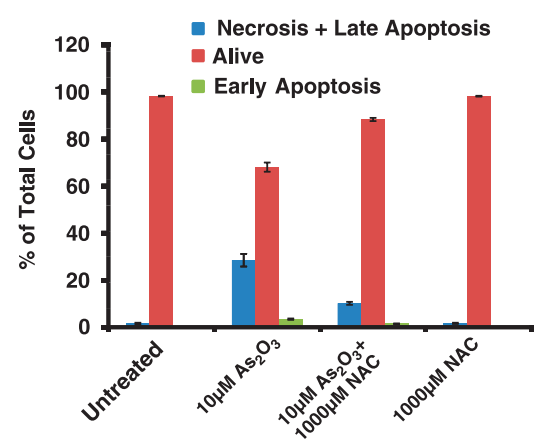

Figure 4 Effects of $\mathrm{As}_{2} \mathrm{O}_{3}$ are reversed by antioxidant. (a) $\mathrm{HEY}$ cells were seeded at 250000 cells per well in a six-well plate. After $24 \mathrm{~h}$, cells were treated with (1) $10 \mu \mathrm{M}$ $\mathrm{As}_{2} \mathrm{O}_{3}$, (2) $10 \mu \mathrm{M} \mathrm{As}_{2} \mathrm{O}_{3}$ and $1000 \mu \mathrm{M} \mathrm{NAC}$, or (3) $1000 \mu \mathrm{M} \mathrm{NAC}$. After $18 \mathrm{~h}$ incubation, the cells were photographed using a light microscope at $\times 40$ magnification. The data shown are representative images. (b) $\mathrm{HEY}$ cells were seeded at 250000 cells per well in a six-well plate. After $24 \mathrm{~h}$ cell attachment, cells were treated with (1) $10 \mu \mathrm{M} \mathrm{As} \mathrm{O}_{3}$ alone, (2) $10 \mu \mathrm{M} \mathrm{As} \mathrm{O}_{3}$ with $100 \mu \mathrm{M} \mathrm{NAC}$, (3) $10 \mu \mathrm{M} \mathrm{As} \mathrm{O}_{3}$ with $500 \mu \mathrm{M} \mathrm{NAC}$, (4) $10 \mu \mathrm{M} \mathrm{As} \mathrm{O}_{3}$ with $1000 \mu \mathrm{M} \mathrm{NAC}$, or (5) $1000 \mu \mathrm{M}$ NAC only. After $18 \mathrm{~h}$ incubation, cell lysates were harvested and western analysis was performed using the following antibodies (left panel): (1) EVI1, (2) SnoN, (3) TAK1, (4) TGF $\beta$ RII, (5) SMAD2/3, and (6) GAPDH as a loading control as well as (right panel): (1) PARP, (2) LC3, (3) p62, and (4) GAPDH. The data shown are representative of three independent experiments. (c) HEY cells were plated at 250000 cells per well in six-well plate onto glass coverslips. After overnight attachment, cells were transfected with EGFP-LC3. After recovery for $24 \mathrm{~h}$, cells were treated with: (1) $10 \mu \mathrm{M} \mathrm{As}_{2} \mathrm{O}_{3}$, (2) $10 \mu \mathrm{M} \mathrm{As}_{2} \mathrm{O}_{3}$ and $1000 \mu \mathrm{M} \mathrm{NAC}$, or (3) $1000 \mu \mathrm{M} \mathrm{NAC}$ for $18 \mathrm{~h}$. (Top panel) immunofluorescence images were obtained at $\times 40$ magnification. (Bottom panel) the displayed graph is the quantification of the data presented as the percentage of EGFP-positive cells with punctate LC3 expression. The data shown are representative of two independent experiments. (d) Cell viability was assessed using the CellTiter-Glo assay in HEY cells treated for $18 \mathrm{~h}$ with $10 \mu \mathrm{M}$ $\mathrm{As}_{2} \mathrm{O}_{3}$ in the absence or presence of $1000 \mu \mathrm{M} \mathrm{NAC}$ or $1000 \mu \mathrm{M} \mathrm{NAC}$ alone. Results are presented as $\%$ cell viability relative to control cells. The data shown are representative of three independent experiments. (e) (Top panel) HEY cells were seeded at 250000 cells per well in six-well plates. After cell attachment, cells were treated with (1) $10 \mu \mathrm{M}$ $\mathrm{As}_{2} \mathrm{O}_{3}$, (2) $10 \mu \mathrm{M} \mathrm{As} \mathrm{O}_{3}$ and $1000 \mu \mathrm{M} \mathrm{NAC}$, and (3) $1000 \mu \mathrm{M} \mathrm{NAC}$, at which time both the floating and adherent cells were collected. Cells were stained with annexin V-FITC and PI followed by flow cytometric analysis. Raw data plots are shown as log fluorescence values of annexin V-FITC and PI on the $X$ and $Y$ axis, respectively. (Bottom panel) the data are also shown in a bar graph as the percentage of viable, early apoptotic, and late apoptotic/necrotic cells. The data shown are representative of three independent experiments 
LC3 RNA transcripts (results not shown) suggesting alternative mechanisms other than direct transcriptional regulation of LC3 by SnoN. As low- and high-expressing EVI1 ovarian cell lines differed in their response to the apoptotic effects of $\mathrm{As}_{2} \mathrm{O}_{3}$ (see Figures $2 \mathrm{a}$ and $\mathrm{b}$ ), we assessed the effect of EVI1 siRNA on the sensitivity of ovarian cancer cells to $\mathrm{As}_{2} \mathrm{O}_{3}$. However, EVI1 siRNA (>90\% reduction in wild-type EVI1 protein) did not dramatically alter $\mathrm{As}_{2} \mathrm{O}_{3}$-induced sensitivity to apoptosis based on PARP cleavage levels or alter autophagy based on western analysis of LC3-II levels (results not shown).

$\mathrm{SnoN}$ is reported to be degraded on $\operatorname{TGF} \beta$ stimulation by TAK1 through the ubiquitin-dependent proteasome pathway. ${ }^{14}$ As we observed that $\mathrm{As}_{2} \mathrm{O}_{3}$ treatment decreased TAK1, we next assessed whether reducing TAK1 levels could alter $\mathrm{As}_{2} \mathrm{O}_{3}$-induced changes in $\mathrm{SnoN}$ and thus, modulate the autophagic pathway. However, TAK1 siRNA treatment ( $>80 \%$ knockdown) did not modulate SnoN levels, alter the sensitivity of ovarian cancer cells to $\mathrm{As}_{2} \mathrm{O}_{3}$, or modulate p62 and LC3 protein levels (Figure 7a). However, knockdown of $\mathrm{AKT}$, which lies downstream to $\mathrm{PI}^{2} \mathrm{~K}^{27}$ and is a promising target for therapy in ovarian carcinomas, ${ }^{28,29}$ did not modulate expression of TGF $\beta$ signaling mediators, but did increase PARP cleavage while decreasing p62 levels and LC3-II/LC3-I levels (Figure $7 \mathrm{~b}$ ) suggesting that AKT has a role in modulating the apoptotic and autophagic pathways.

\section{Discussion}

As successful treatment of cancer cells with chemotherapeutic drugs is dependent on their ability to trigger cell death, it is critical to understand their mechanisms of action. In this study, we report that $\mathrm{As}_{2} \mathrm{O}_{3}$, commonly used to treat $\mathrm{APL}$, can target TGF $\beta$ signaling mediators through proteasomedependent (i.e., EVI1 and TGF $\beta$ RII) and -independent pathways (SMAD2/3 and AKT) in ovarian cancer cell lines. The increased sensitivity of EVI1 forms to $\mathrm{As}_{2} \mathrm{O}_{3}$ after longterm treatments $(18 \mathrm{~h})$ could be due to their inherent protein stability and long half-life. These $\mathrm{As}_{2} \mathrm{O}_{3}$-induced effects on EVI1 are similar to the reported effects in leukemia cell lines. ${ }^{10}$

In our studies, we observed different sensitivities to $\mathrm{As}_{2} \mathrm{O}_{3}$ among the three ovarian cell lines assessed (low- (T80) and high- (SKOV3 and HEY) expressing EVI1 ovarian cell lines) suggesting that the sensitivity of ovarian cell lines to $\mathrm{As}_{2} \mathrm{O}_{3}$ may correlate with EVI1 protein expression. However, knockdown of EVI1 (siRNA designed against exon VII) failed to alter the sensitivity to $\mathrm{As}_{2} \mathrm{O}_{3}$-induced apoptosis. There are numerous other factors likely dictating cellular resistance or sensitivity to $\mathrm{As}_{2} \mathrm{O}_{3}$ including (1) $\mathrm{GSH}$ levels, (2) enzymes involved in biosynthesis of $\mathrm{GSH}$, (3) enzymes using GSH (glutathione-S-transferase), (4) free radical scavenging and peroxide metabolism (GSH peroxidase, catalase), and (5) MRP1 levels, which is involved in the efflux of $\mathrm{As}_{2} \mathrm{O}_{3}$ in drug-resistant cell lines. Indeed, we observed that MRP1 is highly expressed in both HEY and SKOV3 cells, which could result in resistance to $\mathrm{As}_{2} \mathrm{O}_{3}$.

$\mathrm{As}_{2} \mathrm{O}_{3}$ treatment dramatically elevated $\mathrm{SnoN}$ levels likely mediated through a ROS-dependent pathway (Figure 4b).
$\mathrm{As}_{2} \mathrm{O}_{3}$ treatment can generate ROS, a form of oxidative stress, which can induce autophagy. Superoxide anion appears to be the major ROS regulating autophagic process. $^{30}$ As ROS oxidizes cellular lipids, proteins, and DNA causing cellular damage, autophagy serves to prevent accumulation of these damaged toxic products and organelles by sequestering these cellular components into autophagosomes (double-membraned vesicles), which fuse with lysosomes for degradation. Specifically, ROS can oxidize the cysteine protease, ATG4, involved in initiating the conjugation of LC3-I to autophagosomal membranes and its consequent release from the autophagophore membrane. ${ }^{31}$

We also observed that $\mathrm{As}_{2} \mathrm{O}_{3}$ treatment elevated $\mathrm{SnoN}$ levels in a TAK1-independent manner (Figure 7a). Interestingly, normal epithelial cells treated with TRAIL induced cytoprotective autophagy mediated through TAK1, which activates AMP-activated protein kinase leading to inhibition of mammalian target of rapamycin I. ${ }^{32}$ However, under our assay conditions, we did not detect changes in autophagy or apoptosis on depletion of TAK1 in HEY ovarian carcinoma cells (see Figure 7a).

Signaling pathways determining whether cells undergo autophagy or apoptosis are complex. In malignant glioma cells, $\mathrm{As}_{2} \mathrm{O}_{3}$ seems to initiate an autophagic response that leads to cell death. ${ }^{33}$ This contrasts to our data in ovarian cell lines based on inhibitor studies with 3-MA and zVAD-fmk suggesting cell-type-specific effects of $\mathrm{As}_{2} \mathrm{O}_{3}$. Indeed, autophagy has been described as a 'double-edged sword' promoting (1) survival in response to stress and starvation as well as (2) programmed cell death. ${ }^{34}$ Recently, autophagyrelated proteins such as beclin-1 or ATG5/12 do not seem to be required for the autophagic process suggesting alternative non-canonical macroautophagy pathways. ${ }^{35,36}$ In our ovarian carcinoma cells, beclin-1 seemed to be dispensable for inducing $\mathrm{As}_{2} \mathrm{O}_{3}$-mediated autophagic response but was dependent on hVps34.

SnoN protein not only paralleled the autophagy marker (LC3-II) but knockdown of SnoN altered LC3-II/I ratios suggesting that this protein lies downstream to SnoN. Other mediators important in $\mathrm{As}_{2} \mathrm{O}_{3}$-induced programmed cell death include p21, which itself leads to cell cycle arrest and apoptosis. ${ }^{37}$ Indeed, we have previously shown that SnoN knockdown increases p21 protein levels. ${ }^{4}$ Thus, SnoN may have a key role in autophagy to promote cell survival as a protective mechanism against $\mathrm{As}_{2} \mathrm{O}_{3}$-induced cell death (Figure 8). The mechanism by which $\mathrm{SnoN}$ alters autophagosome development is presently under investigation.

\section{Materials and Methods}

Cell lines and cell culture. The following ovarian cell lines were used for the studies reported herein: $\mathrm{T}$ antigen/hTERT immortalized normal ovarian surface epithelial cells (T80) as well as several ovarian carcinoma cell lines, including SKOV3 (amplification at the EVI1 locus), HEY (high-expressing EVI1 cell line), and OVCA429 (high-expressing EVI1 cell line). ${ }^{2}$ Cell lines were cultured in RPMI 1640 with $8 \% \mathrm{FBS}$ and penicillin/streptomycin and maintained in an incubator with a humidified atmosphere containing $95 \%$ air and $5 \% \mathrm{CO}_{2}$ at $37^{\circ} \mathrm{C}$. For nutrient starvation, cells were washed three times with Earle's balanced salt solution (EBSS) (Invitrogen, Carlsbad, CA, USA) and then replaced with EBSS.

siRNA treatment of ovarian cell lines. The ovarian cancer cells, HEY and OVCA429, were plated at 250000 cells (unless otherwise specified) in each well 
of a six-well plate. The following day, the cells were transfected using $20 \mu \mathrm{M}$ siRNA against SnoN (Ambion, Austin, TX, USA), ID\#107696 or ID\#107695), EVI1 exon VII (Dharmacon, Lafayette, CO, USA), custom-designed sequence: sense $5^{\prime}$-ACUACGUCUUCCUUAAAUAUU- ${ }^{\prime}$ ), AKT (Cell Signaling Technology, Danvers, MA, USA), TAK1 (Dharmacon, custom-designed sequence: sense 5'-GUAGAUCCAUCCAAGACUUUU-3'), SMURF2 (Dharmacon, L-007194-00),
ATG5 (Dhamarcon, L-004374-00), beclin-1 (Dharmacon, L-010552-00), ATG7 (Dharmacon, L-020112-00), hVps34 (Applied Biosystems, Foster City, CA, USA ID\#10517), or non-targeting control-1 siRNA (Dharmacon, D-001210-01) using Dharmafect I transfection reagent (Dharmacon). Briefly, cells were cultured in complete medium for $24 \mathrm{~h}$ before transfection $(2 \mathrm{ml}$ media in each well of six-well plate) at which time the medium was changed to serum and antibiotic-free medium. a
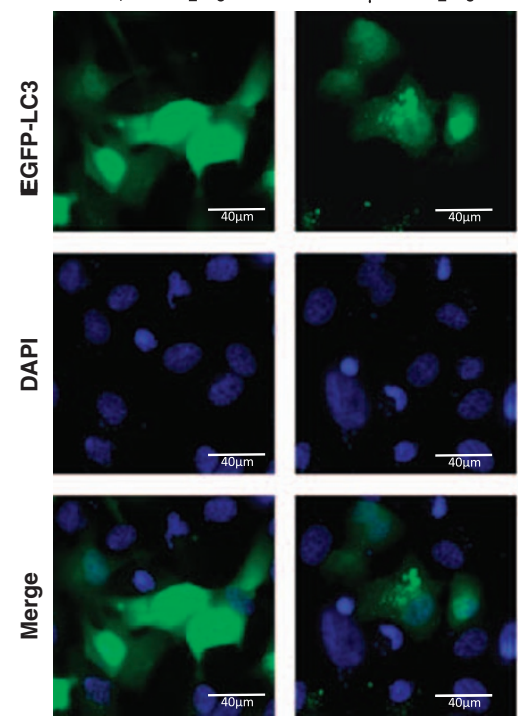

b

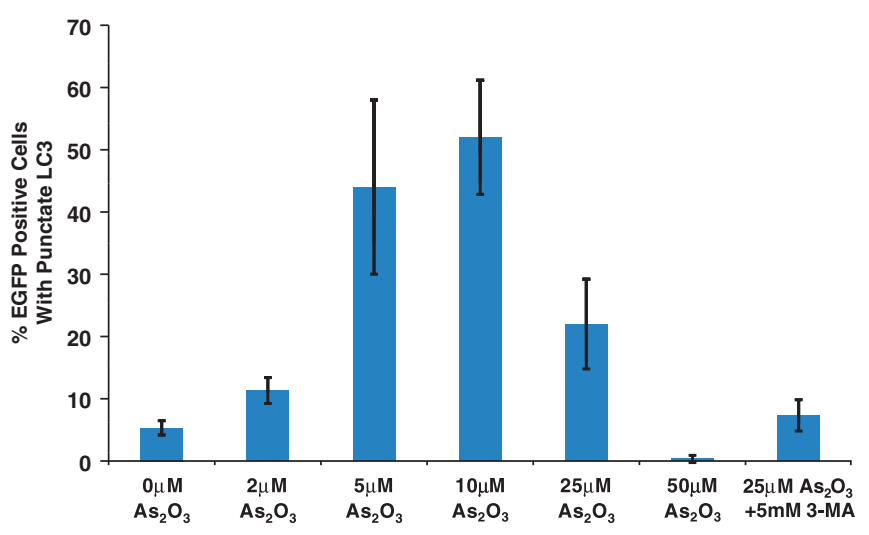

d

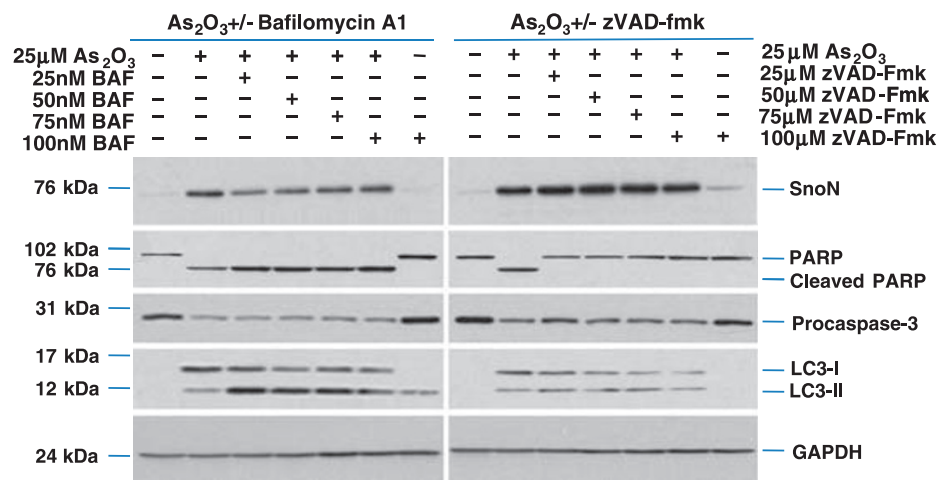

$5 \mu \mathrm{M} \mathrm{As}_{2} \mathrm{O}_{3}$
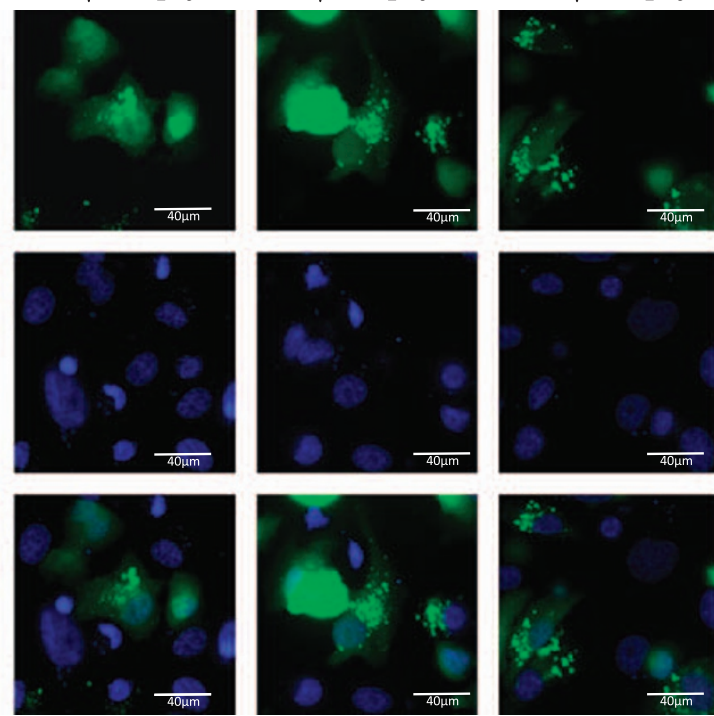
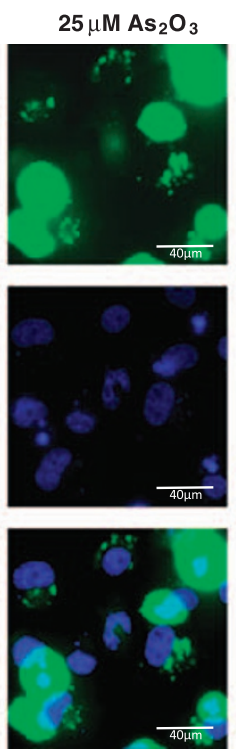

$25 \mu \mathrm{M} \mathrm{As}{ }_{2} \mathrm{O}_{3}$ $+5 \mathrm{mM}$ 3-MA
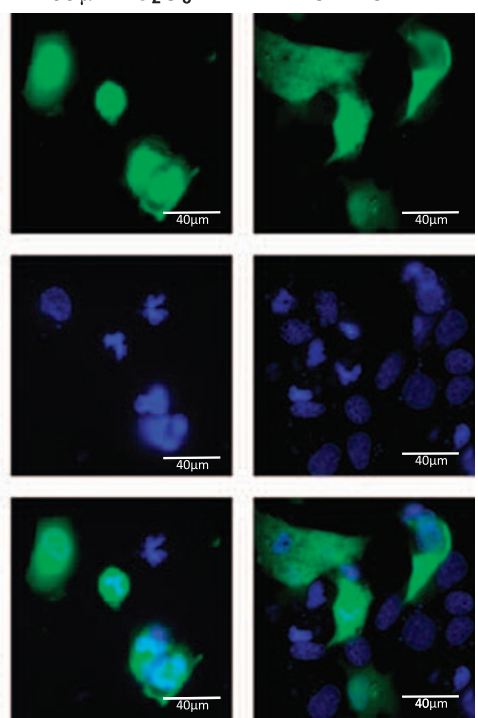

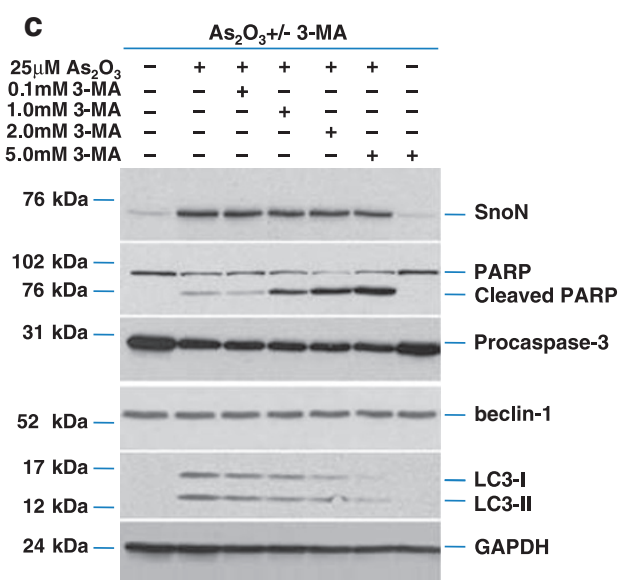

Ovarian Cell Lines
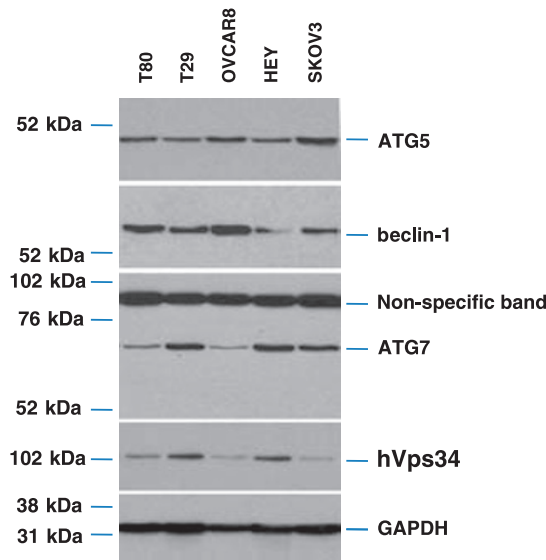

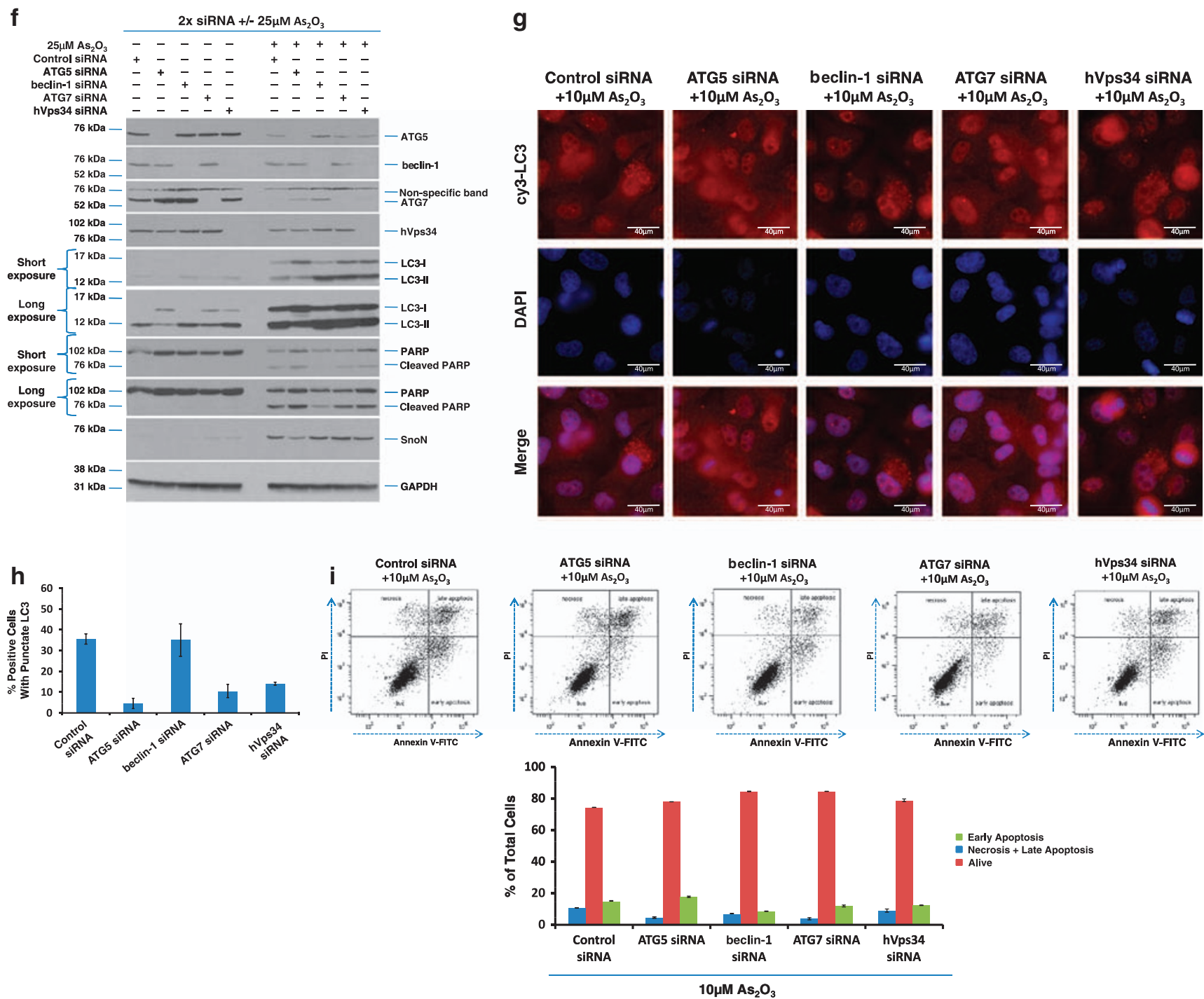

Figure $5 \quad \mathrm{As}_{2} \mathrm{O}_{3}$ induces autophagy through a beclin-1-independent pathway. (a) $\mathrm{HEY}$ cells were plated at 250000 cells per well in six-well plate onto glass coverslips. After overnight attachment, cells were transfected with EGFP-LC3. After recovery for $24 \mathrm{~h}$, cells were treated with increasing doses of $\mathrm{As}_{2} \mathrm{O}_{3}(2-50 \mu \mathrm{M})$ or $25 \mu \mathrm{M} \mathrm{As} \mathrm{O}_{3}$ in the presence of $5 \mathrm{mM} 3-\mathrm{MA}$ for $18 \mathrm{~h}$. Immunofluorescence images were obtained at $\times 40$ magnification. The data shown are representative of two independent experiments. (b) Immunofluorescence data from (a) was quantitated and presented as the percentage of EGFP-positive cells with punctate LC3 expression. (c) HEY cells were seeded at 250000

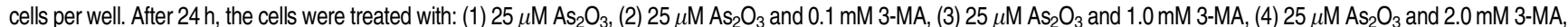
(5) $25 \mu \mathrm{M} \mathrm{As}_{2} \mathrm{O}_{3}$ and $5.0 \mathrm{mM}$ 3-MA, and (6) $5.0 \mathrm{mM}$ 3-MA only for $18 \mathrm{~h}$. Cell lysates were harvested and western analysis was performed using the following antibodies: (1) SnoN, (2) PARP, (3) procaspase-3, (4) beclin-1, (5) LC3, and (6) GAPDH as a loading control. The data shown are representative of four independent experiments. (d) HEY cells were seeded at 250000 cells per well. (Left panel): after overnight attachment, the cells were treated with: (1) $25 \mu \mathrm{M} \mathrm{As} \mathrm{O}_{3}$ (2) $25 \mu \mathrm{M} \mathrm{As} \mathrm{O}_{2}$ and $25 \mathrm{nM}$ bafilomycin A (BAF), (3) $25 \mu \mathrm{M} \mathrm{As} \mathrm{O}_{3}$ and $50 \mathrm{nM} \mathrm{BAF}$, (4) $25 \mu \mathrm{M} \mathrm{As}_{2} \mathrm{O}_{3}$ and $75 \mathrm{nM} \mathrm{BAF}$, (5) $25 \mu \mathrm{M} \mathrm{As}_{2} \mathrm{O}_{3}$ and $100 \mathrm{nM} \mathrm{BAF}$, and (6) $100 \mathrm{nM} \mathrm{BAF}$ only. (Right panel): after $24 \mathrm{~h}$, the cells were treated with: (1) $25 \mu \mathrm{M} \mathrm{As} 2 \mathrm{O}_{3}$, (2) $25 \mu \mathrm{M} \mathrm{As}_{2} \mathrm{O}_{3}$ and $25 \mu \mathrm{M}$ zVAD-Fmk, (3) $25 \mu \mathrm{M} \mathrm{As} \mathrm{O}_{3}$ and $50 \mu \mathrm{M}$ zVAD-Fmk, (4) $25 \mu \mathrm{M} \mathrm{As} \mathrm{O}_{3}$ and $75 \mu \mathrm{M} \mathrm{zVAD}-F m k$, (5) $25 \mu \mathrm{M} \mathrm{As} \mathrm{O}_{3}$ and $100 \mu \mathrm{M}$ zVAD-Fmk, and (6) $100 \mu \mathrm{M}$ zVAD-Fmk only. After $18 \mathrm{~h}$ incubation, cell lysates were harvested and western analysis was performed using the following antibodies: (1) SnoN, (2) PARP, (3) procaspase-3, (4) LC3, and (5) GAPDH as a loading control. The data shown are representative of two independent experiments. (e) Ovarian cells (T80, T29, OVCAR8, HEY, and SKOV3 cells) were seeded at 500000 cells per well in T-25 flasks. After overnight attachment, cell lysates were harvested and western analysis was performed using the following antibodies: (1) ATG5, (2) beclin-1, (3) ATG7, (4) (5) hVps34, and (6) GAPDH as a loading control. (f) HEY cells were seeded at 250000 cells per well in six-well plates. After 24 and $48 \mathrm{~h}$, the cells were treated with (1) non-targeting (control) siRNA, (2) ATG5 siRNA, (3) beclin-1 siRNA, (4) ATG7 siRNA, and (5) hVps34 siRNA. At $72 \mathrm{~h}$ after transfection, cells were treated for $18 \mathrm{~h}$ with $25 \mu \mathrm{M} \mathrm{As}_{2} \mathrm{O}_{3}$. Cell lysates were harvested and western analysis was performed using the following antibodies: (1) ATG5, (2) beclin-1, (3) ATG7, (4) hVps34, (5) LC3, (6) PARP, (7) SnoN, and (8) GAPDH as a loading control. The data shown are representative of two independent experiments. (g) HEY cells were seeded at 250000 cells per well in six-well plates. After 24 and $48 \mathrm{~h}$, the cells were treated with (1) non-targeting (control) siRNA, (2) ATG5 siRNA, (3) beclin-1 siRNA, (4) ATG7 siRNA, and (5) hVps34 siRNA. At $72 \mathrm{~h}$ after transfection, cells were treated for $24 \mathrm{~h}$ with $10 \mu \mathrm{M} \mathrm{As}_{2} \mathrm{O}_{3}$. Cells were stained with LC3B rabbit polyclonal antibody and counterstained with DAPI. Immunofluorescence images are representative and were obtained at $\times 63$ magnification. (h) Immunofluorescence data was quantitated and presented as the percentage of positive cells with punctate LC3 expression. The data shown are representative of two independent experiments. (i) HEY cells were seeded at 250000 cells per well in six-well plates. After 24 and $48 \mathrm{~h}$, the cells were treated with (1) non-targeting (control) siRNA, (2) ATG5 siRNA, (3) beclin-1 siRNA, (4) ATG7 siRNA, and (5) hVps34 siRNA. At $72 \mathrm{~h}$ after transfection, cells were treated for $48 \mathrm{~h}$ with $10 \mu \mathrm{M} \mathrm{As}_{2} \mathrm{O}_{3}$ at which time both the floating and adherent cells were collected. Cells were stained with annexin V-FITC and PI followed by flow cytometric analysis. Raw data plots are shown as log fluorescence values of annexin V-FITC and PI on the $X$ and $Y$ axis, respectively (top panel). The data are also shown as a bar graph as the percentage of viable, early apoptotic, and late apoptotic/necrotic cells. The data shown are representative of two independent experiments (bottom panel) 
Dharmafect I ( $4 \mu$ l) was incubated in $100 \mu$ of serum and antibiotic-free media for $10 \mathrm{~min}$ at room temperature, followed by the addition of $5 \mu \mathrm{l}$ of siRNA $(20 \mu \mathrm{M})$ and further incubated for $20 \mathrm{~min}$ at room temperature. The mixture was added to the cells and incubated for $48 \mathrm{~h}$ before isolation of RNA and protein for QPCR and western analysis, respectively.
Cell treatments with clinical inhibitors. The clinical inhibitors $\mathrm{As}_{2} \mathrm{O}_{3}$ and MG132 (dissolved in DMSO) were obtained from Sigma-Aldrich (St. Louis, MO, USA) and Alexis Biochemicals (Farmingdale, NY, USA), respectively. NAC (dissolved in media) and Bortezomib (PS-341; dissolved in DMSO) were obtained from Fisher Scientific. Resveratrol (dissolved in DMSO) was obtained from EMD

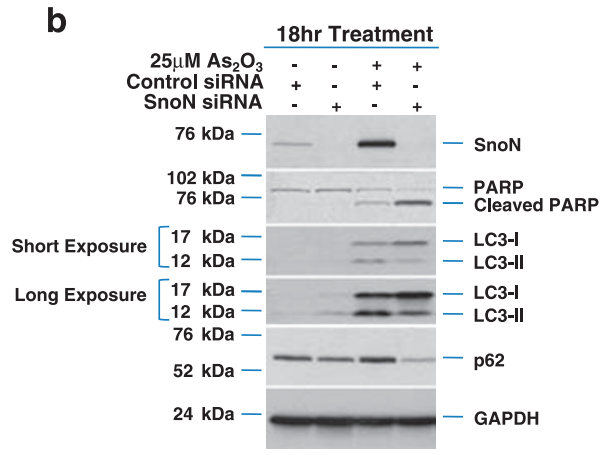

C
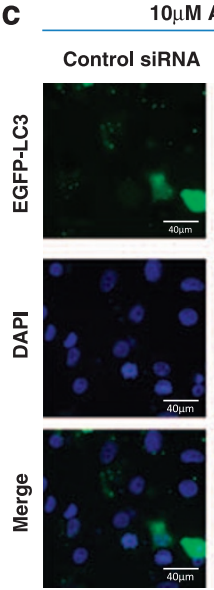

.
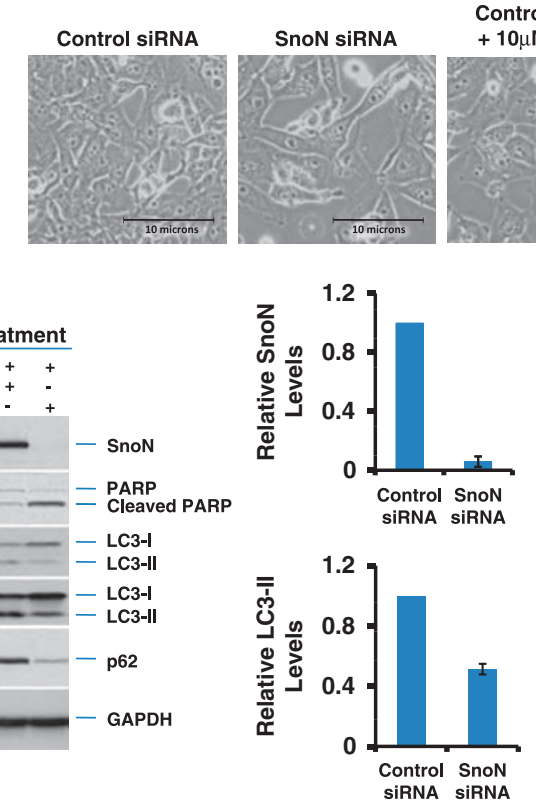
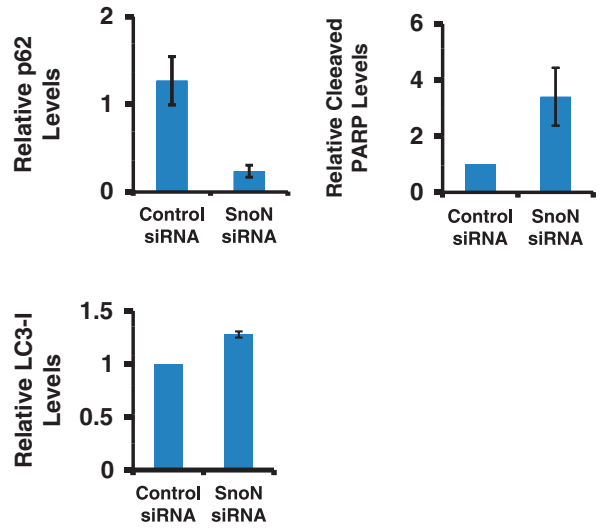

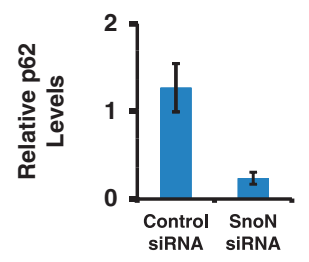

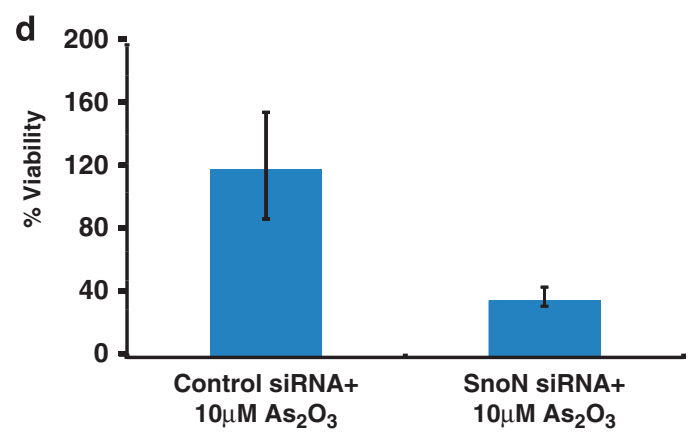
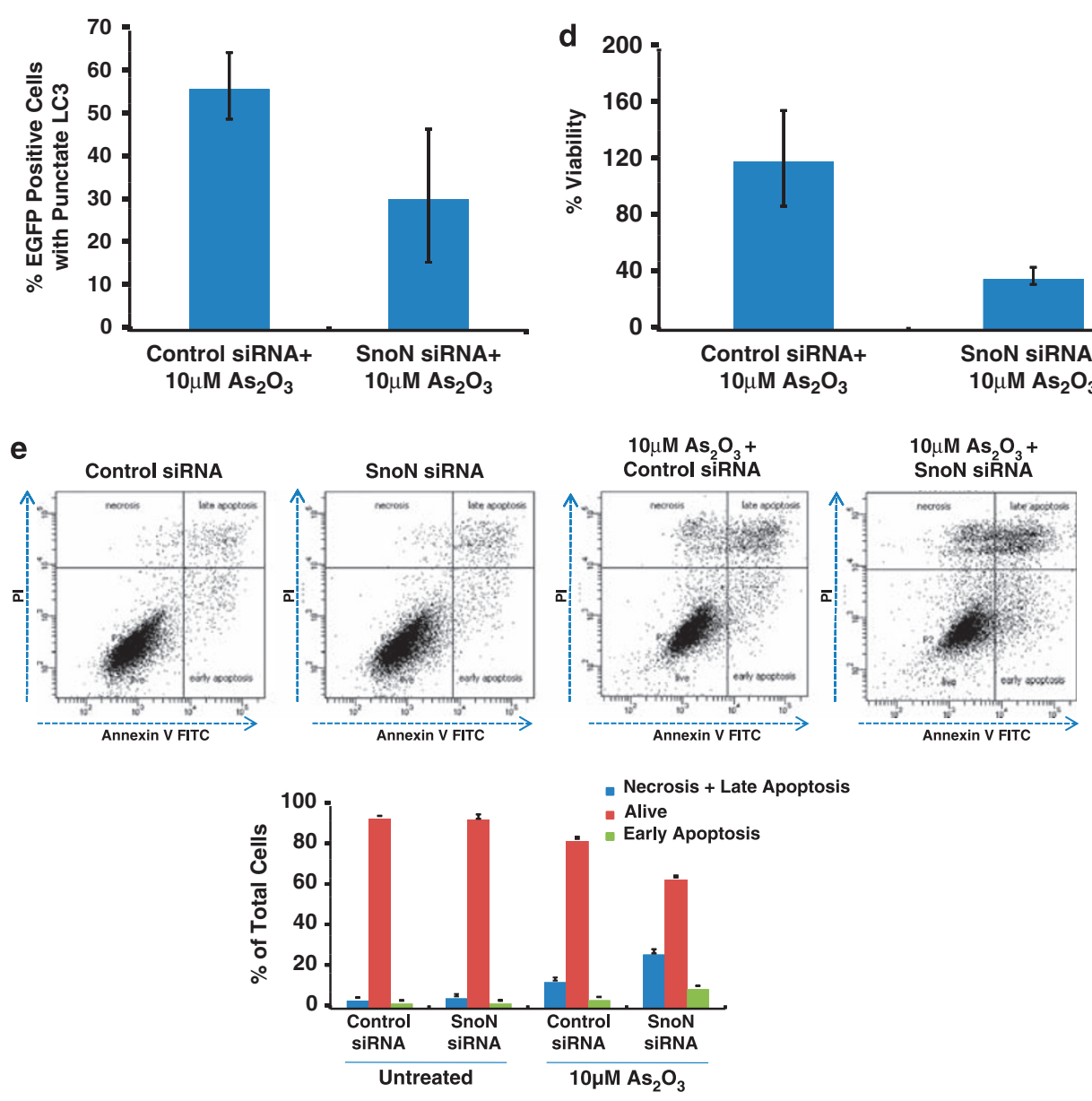
Biosciences (Gibbstown, NJ, USA). 3-MA(dissolved in media) was obtained from MP Biomedicals (Solon, OH, USA). zVAD-fmk (dissolved in DMSO) and BAF (dissolved in DMSO) was obtained from Axxora LLC (San Diego, CA, USA). Ovarian cells were plated in six-well plates at 250000 cells per well and grown in complete medium. The following day, the cells were treated with $5 \mu \mathrm{M} \mathrm{MG} 132, \mathrm{As}_{2} \mathrm{O}_{3}$ (between 2 and $50 \mu \mathrm{M}$ ), resveratrol (between 10 and $100 \mu \mathrm{M}$ ), NAC (between $25 \mu \mathrm{M}$ and $1 \mathrm{mM}$ ), 3-MA (between 0.1 and $10 \mathrm{mM}$ ), or ZVAD-fmk (25 and $100 \mu \mathrm{M}$ ). For detection of apoptosis by western analysis, it was generally difficult to detect cleaved PARP at $10 \mu \mathrm{M} \mathrm{As} \mathrm{O}_{3}$ treatment but it was clearly observable with $25 \mu \mathrm{M} \mathrm{As}_{2} \mathrm{O}_{3}$ (see Figure $3 \mathrm{a}$ ). For functional assays (cell viability, apoptosis by PI/Annexin V staining, and EGFP-LC3 staining), we treated cells with
$10 \mu \mathrm{M} \mathrm{As} \mathrm{O}_{3}$, which allowed detection of differences more clearly with various treatments including siRNA knockdown (see Figure 2c). For control cells, DMSO (a final concentration of $<0.5 \%$ ) was added to compare appropriately with drugs dissolved in DMSO. After the appropriate incubation time (6 or $18 \mathrm{~h}$ ), cell lysates were collected, protein quantified, and SDS-PAGE/western analysis was performed. In addition, for selected studies, RNA was isolated, quantified, and used for qPCR analysis.

Quantitative PCR. RNA was isolated using the RNeasy Mini Kit (Qiagen, Valencia, CA, USA). Quantitative PCR (qPCR) was performed using the one-step RT-PCR Taqman master mix from Applied Biosystems with the following primers and probe sets.

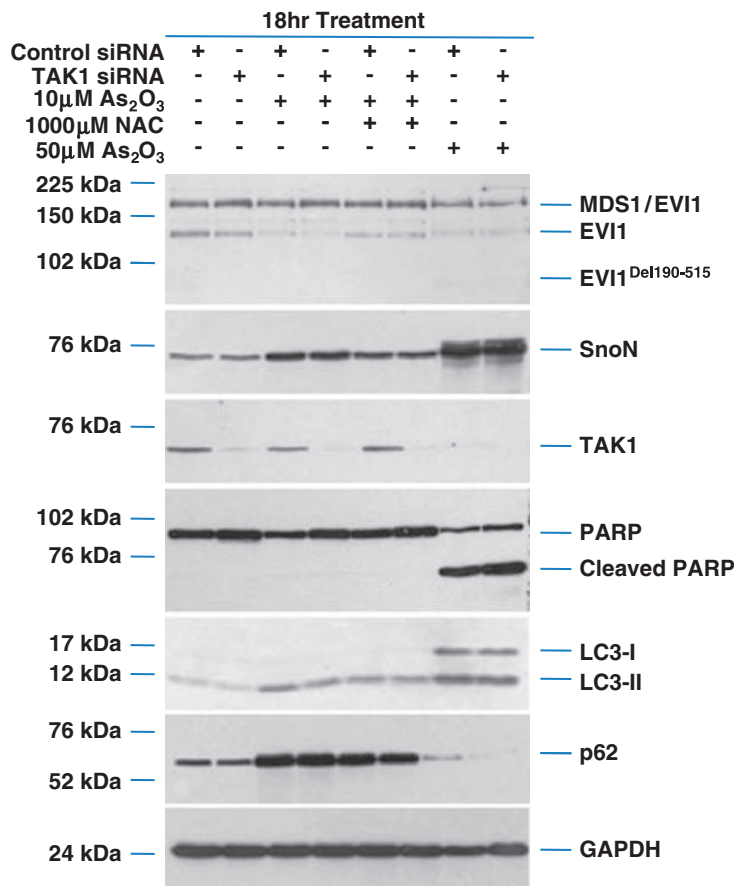

b

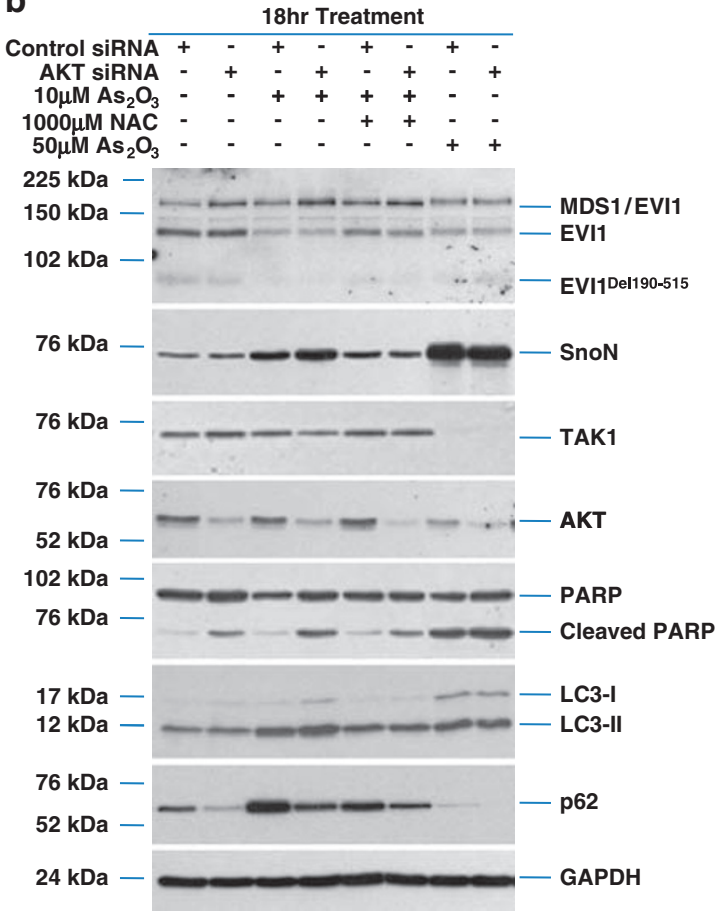

Figure 7 AKT knockdown modulates apoptosis in response to $\mathrm{As}_{2} \mathrm{O}_{3}$. (a) $\mathrm{HEY}$ cells were seeded at 375000 cells per well in six-well plates. After $24 \mathrm{~h}$ attachment, cells were transfected with either non-targeting (control) or TAK1 siRNA. Transfected cells were then treated for $18 \mathrm{~h}$ with (1) $10 \mu \mathrm{M} \mathrm{As} \mathrm{O}_{3}$, (2) $10 \mu \mathrm{M} \mathrm{As} 2 \mathrm{O}_{3}$ with $1 \mathrm{mM}$ NAC, and (3) $50 \mu \mathrm{M} \mathrm{As}_{2} \mathrm{O}_{3}$. Cell lysates were harvested and western analysis was performed using the following antibodies (1) EVl1, (2) SnoN, (3) TAK1, (4) PARP, (5) LC3, (6) p62, and (7) GAPDH as a loading control. The data shown are representative of two independent experiments. (b) HEY cells were seeded at 375000 cells per well in six-well plates. After $24 \mathrm{~h}$ attachment, cells were transfected with either non-targeting (control) or AKT siRNA. Transfected cells were then treated for $18 \mathrm{~h}$ with (1) $10 \mu \mathrm{M} \mathrm{As} \mathrm{O}_{3},(2) 10 \mu \mathrm{M}$ $\mathrm{As}_{2} \mathrm{O}_{3}$ with $1 \mathrm{mM} \mathrm{NAC}$, and (3) $50 \mu \mathrm{M} \mathrm{As}_{2} \mathrm{O}_{3}$. Cell lysates were harvested and western analysis was performed using the following antibodies: (1) EVI1, (2) SnoN, (3) TAK1, (4) AKT, (5) PARP, (6) LC3, (7) p62, and (8) GAPDH as a loading control. The data shown are representative of two independent experiments

Figure 6 Knockdown of $\mathrm{SnoN}$ modulates the sensitivity of ovarian cancer cells to $\mathrm{As}_{2} \mathrm{O}_{3}$. (a) $\mathrm{HEY}$ cells were plated at 250000 cells per well in six-well plate. After overnight attachment, the cells were transiently transfected with (1) non-targeting (control) siRNA or (2) SnoN siRNA. At $24 \mathrm{~h}$ after transfection, the cells were treated with $10 \mu \mathrm{M} \mathrm{As} 2 \mathrm{O}_{3}$. After $18 \mathrm{~h}$, light microscope images were captured at $\times 40$ magnification. The data shown are representative images. (b) (Left panel) HEY cells were seeded at 250000 cells per well in six-well plates. After $24 \mathrm{~h}$, the cells were transiently transfected with (1) non-targeting (control) siRNA or (2) SnoN siRNA. At $24 \mathrm{~h}$ after transfection, the cells were treated with $25 \mu \mathrm{M} \mathrm{As}_{2} \mathrm{O}_{3}$. After $18 \mathrm{~h}$ incubation, cell lysates were harvested and western analysis was performed using the following antibodies: (1) SnoN, (2) PARP, (3) LC3, (4) p62, and (4) GAPDH as a loading control. The data shown are representative of two independent experiments. (Right panel) densitometric analyses of selected western data (only $\mathrm{As}_{2} \mathrm{O}_{3}$-treated samples), which include SnoN, cleaved PARP, LC3-I, LC3-II, and p62. (c) (Left panel) HEY cells were plated at 250000 cells per well in six-well plate onto glass coverslips. After overnight attachment, cells were transfected with EGFP-LC3. After recovery for $24 \mathrm{~h}$, cells were treated with (1) non-targeting (control) siRNA or (2) SnoN siRNA followed by cell treatment with $10 \mu \mathrm{M} \mathrm{As}_{2} \mathrm{O}_{3}$. Immunofluorescence images are representative and were obtained at $\times 40$ magnification. (Right panel) immunofluorescence data were quantitated and presented as the percentage of EGFP-positive cells with punctate LC3 expression. The data shown are representative of two independent experiments. (d) Cell viability was assessed using the CellTiter-Glo assay in HEY cells transfected with control or SnoN siRNA followed by treatment for $18 \mathrm{~h}$ with $10 \mu \mathrm{M} \mathrm{As}_{2} \mathrm{O}_{3}$. Results are presented as \% cell viability relative to non-targeting (control) siRNA-treated cells. The data shown are representative of two independent experiments. (e) (Top panel) HEY cells were seeded at 250000 cells per well in six-well plates. After $24 \mathrm{~h}$, cells were treated with (1) non-targeting (control) siRNA or (2) SnoN siRNA. At $24 \mathrm{~h}$ after transfection, cells were treated for $48 \mathrm{~h}$ with $10 \mu \mathrm{M} \mathrm{As}_{2} \mathrm{O}_{3}$ at which time both the floating and adherent cells were collected. Cells were stained with annexin V-FITC and PI followed by flow cytometric analysis. Raw data plots are shown as log fluorescence values of annexin V-FITC and PI on the $X$ and $Y$ axis, respectively. (Bottom panel) the data are shown in a bar graph as the percentage of viable, early apoptotic, and late apoptotic/necrotic cells. The data shown are representative of three independent experiments 


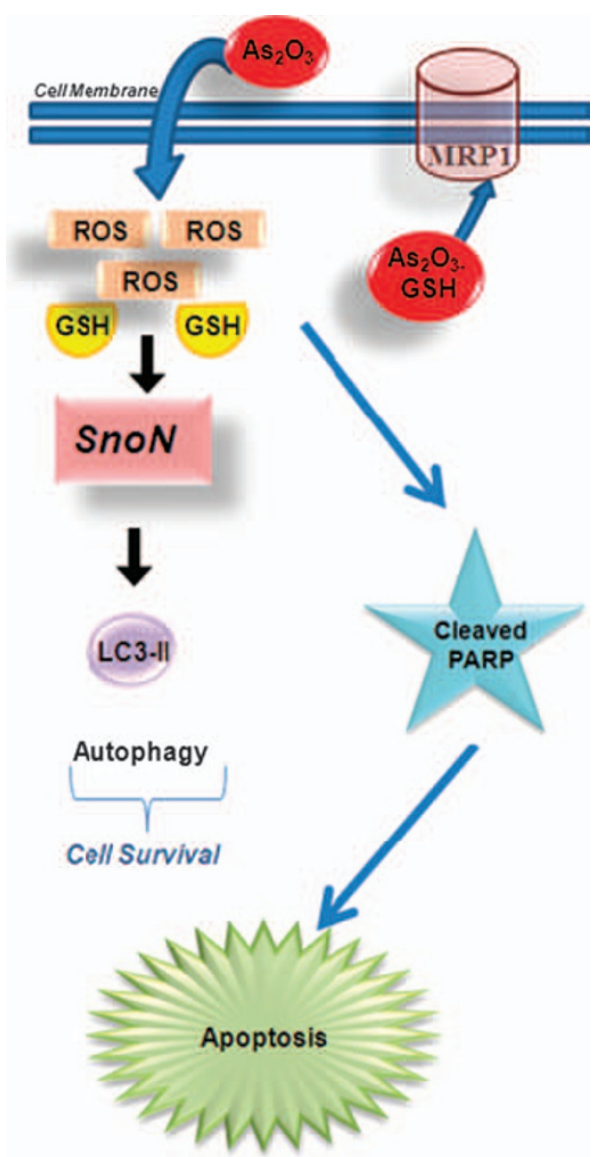

Figure 8 Therapeutic potential for $\mathrm{SnoN}$ in mediating $\mathrm{As}_{2} \mathrm{O}_{3}$-induced autophagic cell survival. $\mathrm{As}_{2} \mathrm{O}_{3}$ diffuses into the cell through the cell membrane leading to a reduction in intracellular GSH levels and an increase in ROS which through unknown mechanisms lead to increases in SnoN levels. SnoN alters LC3-II expression, a marker of autophagosome maturation, suggesting that SnoN can induce autophagy. Induction of autophagy seems to be a protective mechanism of cell survival following $\mathrm{As}_{2} \mathrm{O}_{3}$ treatment in ovarian cells. In high MRP1-expressing cell lines, $\mathrm{As}_{2} \mathrm{O}_{3}$ is effluxed through these channels resulting in reduced sensitivity to $\mathrm{As}_{2} \mathrm{O}_{3}$-induced apoptosis

EVI1 exon III - (detects both EVI1 and MDS1/EVI1):

Forward primer, 5'-CGAAGACTATCCCCATGAAACTATG-3';

Reverse primer, $5^{\prime}$-TCACAGTCTTCGCAGCGATATT-3';

Probe sequence, $5^{\prime}$-TCCACGAAGACGGA- $3^{\prime}$.

Primers/probe sequences for SnoN (Hs00180524_m1), TGF $\beta$ RII (Hs00234253_m1), and LC3 (Hs00261291_m1) were obtained from Applied Biosystems (Assays by design). mRNA levels were determined using the One-StepPlus Applied Biosystems Detection System using $\beta$-actin as a reference. PCR conditions were as follows: stage I: $48^{\circ} \mathrm{C}$ for $30 \mathrm{~min}$; stage II: $95^{\circ} \mathrm{C}$ for $10 \mathrm{~min}$; stage III: (40 cycles) $95^{\circ} \mathrm{C}$ for $15 \mathrm{~s}$ followed by $60^{\circ} \mathrm{C}$ for $1 \mathrm{~min}$. Using the correlative method, RNA-fold change in expression was calculated as $\mathrm{Ct}$ of gene - $\mathrm{Ct}$ of $\beta$-actin to generate delta $\mathrm{Ct}$ from which delta $\mathrm{Ct}$ of the normal sample was subtracted. These values were then converted to $\log _{2}$ values.

SDS-PAGE and western blot analyses. Proteins were resolved on an 8 , 12 , or $15 \%$ SDS-PAGE gel (as appropriate) and electrophoretically transferred to polyvinyldifluoride (PVDF) membranes. After blocking with $5 \%(\mathrm{w} / \mathrm{v})$ milk in TBST (tris-buffered saline containing $0.1 \%$ Tween-20) for $1 \mathrm{~h}$ at room temperature, membranes were incubated with primary antibodies (at appropriate dilution) overnight at $4{ }^{\circ} \mathrm{C}$, followed by extensive washing and incubation for $1 \mathrm{~h}$ with the appropriate horseradish peroxidase-conjugated secondary antibodies (Bio-Rad, Hercules, CA, USA). Blots were washed extensively and developed using chemiluminescence substrate (Bio-Rad). A rabbit polyclonal EVI1 antibody was obtained from Dr. J Ihle (1: 3000 dilution, St. Jude's Children's Hospital, Memphis, TN, USA). SnoN rabbit polyclonal (1:1000 dilution), SMURF2 rabbit polyclonal (1:500 dilution), MRP1 mouse monoclonal (1:500 dilution) and GAPDH mouse monoclonal (1:250 dilution) antibodies were obtained from Santa Cruz Biotechnology (Santa Cruz, CA, USA). TGF $\beta$ RII rabbit polyclonal $(1: 1000$ dilution) antibody was obtained from Strategic Diagnostics (Newark, DE, USA). SMAD2/3 rabbit polyclonal (1:1000 dilution), AKT rabbit polyclonal (1:1000 dilution), TAK1 rabbit polyclonal (1:1000 dilution), PARP rabbit polyclonal (1:1000 dilution), beclin-1 rabbit polyclonal (1:1000 dilution), caspase-3 rabbit polyclonal (1:1000, which detects the pro-caspase form), ATG5 rabbit polyclonal (1:1000 dilution), hVps34 rabbit polyclonal (1: 1000 dilution), LC3 rabbit polyclonal (1:1000 dilution) antibodies were obtained from Cell Signaling Technology. The p62 Dok mouse monoclonal (1:1000 dilution) antibody was obtained from BD Biosciences (San Jose, CA, USA). The ATG7 rabbit polyclonal (1:1000 dilution) antibody was obtained from MBL International (Woburn, MA, USA).

Densitometric analysis was performed using the $\mathrm{Hp}$ Scanjet 5590 and the Image $J$ program (Image Processing and Analysis in Java, NIH Image Software, http://rsb.info.nih.gov/ij/). Bands were selected and the intensity values were normalized to those for GAPDH. The values are presented as fold-changes relative to control siRNA-treated cells.

Migration assays. Immortalized normal ovarian epithelial cells (T80) and ovarian cancer cells (SKOV3 and HEY) were treated with $5 \mu \mathrm{M} \mathrm{As}_{2} \mathrm{O}_{3}$ for $6 \mathrm{~h}$. In all, 25000 cells were seeded into each Boyden chamber insert. After $18 \mathrm{~h}$, the cells were fixed and stained with crystal violet. The cells that migrated through the pores were counted using an inverted light microscope.

Cell viability assay through measurement of intracellular ATP levels. T80, HEY, and SKOV3 ovarian cells were seeded in triplicate for each treatment group at 5000 cells per well into each well of a 96 -well white-opaque plate. After overnight cell attachment, cells were treated for $18 \mathrm{~h}$ with appropriate doses of $\mathrm{As}_{2} \mathrm{O}_{3}(2,5,10,25$, and $50 \mu \mathrm{M})$. After termination of the cell treatments, the media was removed from the wells and replaced with $100 \mu$ l of phosphate-buffered saline (PBS). The plate was equilibrated to room temperature, $100 \mu$ of CellTiter-Glo reagent (Promega, Madison, WI, USA) was added, and mixed on a plate shaker for $2 \mathrm{~min}$. The plate was further incubated for $10 \mathrm{~min}$ at room temperature before reading with a Biotek (Biotek Instruments Incorporated, Winooski, VT, USA) luminescence plate reader to obtain relative light unit (RLU) measurements. Empty wells (containing no cells) were used as a correction for background luminescence. All experiments were performed in triplicate.

Apoptosis assays. For assessment of apoptosis, the Annexin V-PI staining kit (Calbiochem, San Diego, CA, USA) was used according to the manufacturer's protocol. Briefly, cells were treated with $\mathrm{As}_{2} \mathrm{O}_{3}$ for $24 \mathrm{~h}$ at which time both the floating and adherent cells (removed by trypsinization) were collected. Cells were resuspended in PBS followed by the addition of annexin V-FITC and PI. The samples were then analyzed by flow cytometry at the MD Anderson Cancer Center and University of South Florida Health - College of Medicine FACS Core Facility. The FITC and the PI signals were detected at $518 \mathrm{~nm}$ with FL1 and at $620 \mathrm{~nm}$ with FL2, respectively. The log fluorescence values of annexin V-FITC and PI are showed on the $X$ and $Y$ axis, respectively.

Electron microscopy. To show the induction of autophagy in $\mathrm{As}_{2} \mathrm{O}_{3}$-treated cells morphologically, $\mathrm{HEY}$ cells were treated with or without $\mathrm{As}_{2} \mathrm{O}_{3}$ (dose) across a series of time points $(\mathrm{h})$ in T-75 culture flasks. Cells were then fixed in $2.5 \%$ glutaraldehyde in $0.1 \mathrm{M}$ phosphate buffer overnight at $4{ }^{\circ} \mathrm{C}$. After rinsing in buffer, cells were scraped from the culture flasks, washed, and then post-fixed in $1 \%$ osmium tetroxide in buffer. After dehydration in a graded series of acetone, the cells were embedded in Embed 812 epoxy resin. Thin sections $(70 \mathrm{~nm})$ were cut on an Ultramicrotome. The sections on the grids were stained with uranyl acetate and lead citrate. The sections were examined on a Transmission Electron Microscope (Morgagni 268D Transmission Electron Microscope, FEl Company, Hillboro, OR, USA).

Indirect immunofluorescence. HEY cells were seeded onto glass coverslips and allowed to adhere after overnight incubation. The cells were then transiently transfected with EGFP-LC3 (Addgene, Cambridge, MA, USA) and allowed to recover for $24 \mathrm{~h}$. The cells were treated at the appropriate concentrations of $\mathrm{As}_{2} \mathrm{O}_{3}$ in the absence or presence of 3-MA ( 5 and $10 \mathrm{mM}$ ) for $18 \mathrm{~h}$. The cells were 
then fixed in 4\% formaldehyde in PBS for 30 min at room temperature, washed twice in PBS, and blocked for $1 \mathrm{~h}$ at room temperature in PBS containing $5 \%$ goat serum and $0.1 \%$ Triton X-100. The cells were washed three times for 5 min in PBS, antiFade containing DAPI nuclear stain was then applied, coverslips mounted onto glass slides and viewed under a Zeiss (Carl Zeiss Incorporated, Thornwood, NY, USA) inverted fluorescence microscope (Moffitt Cancer Center Microscopy Core). Quantification of EGFP-LC3-expressing cells was assessed by counting the number of cells containing punctate dots in a total of 200 EGFP-LC3-positive cells.

For indirect immunofluorescence of endogenous LC3B expression, HEY cells fixed in $4 \%$ formaldehyde in PBS for $30 \mathrm{~min}$ at room temperature, washed twice in PBS, and blocked for $1 \mathrm{~h}$ at room temperature in PBS containing $5 \%$ goat serum and $0.1 \%$ Triton X-100. Primary antibodies (LC3B used at 1:2000 dilution) were incubated in PBS containing $1 \%$ goat serum and $0.1 \%$ Triton X-100 overnight at $4{ }^{\circ} \mathrm{C}$. The cells were washed three times for $5 \mathrm{~min}$ in PBS and then incubate with the appropriate cy3-fluorescent-conjugated rabbit antibody for $1 \mathrm{~h}$ in PBS containing $1 \%$ goat serum and $0.1 \%$ Triton $X-100$. The cells were washed three times for 5 min in PBS, anti-Fade containing DAPI nuclear stain was then applied, coverslips mounted onto glass slides, and viewed under a fluorescence microscope.

GSH measurement assays. GSH was measured using the GSH-Glo kit (Promega). Briefly, T80, HEY, and SKOV3 ovarian cells were plated at 5000 cells per well in opaque white 96-well plates. After overnight attachment, cells were treated with $\mathrm{As}_{2} \mathrm{O}_{3}$ for $18 \mathrm{~h}$. After cell treatments, the media was discarded and fresh PBS was added for washout followed by the addition of $100 \mu \mathrm{l}$ of GSH-Glo reagent. After a 2-min shake, the cells were incubated at room temperature for $30 \mathrm{~min}$ followed by the addition of reconstituted luciferase detection reagent. The cells were incubated for a further $15 \mathrm{~min}$ at room temperature and the plate was read on a Biotek luminescence plate reader. All measurements were performed in triplicate.

Statistical analyses. Values are reported as the mean \pm S.D. of independent experiments (see Figure legends). In cell viability assays, the data are normalized to control cells and expressed as the percentage of live cells relative to total cells.

\section{Conflict of interest}

The authors declare no conflict of interest.

Acknowledgements. This work was supported by R01 CA123219 to GBM and MN as well as University of South Florida Startup funds to MN. This work has been supported in part by the Flow Cytometry Core Facility at the MD Anderson Cancer Center and University of South Florida. We gratefully acknowledge Dr. Kenyon Daniel for discussion and critical reading of the paper. We also kindly acknowledge Mitchel Ruzek, Deena Whaba, Christie Campla, and Kyle Bauckman for their assistance on the studies reported herein.

1. Elliott RL, Blobe GC. Role of transforming growth factor beta in human cancer. J Clin Oncol 2005; 23: 2078-2093

2. Nanjundan M, Nakayama Y, Cheng KW, Lahad J, Liu J, Lu K et al. Amplification of MDS1/ EVI1 and EVI1, located in the 3q26.2 amplicon, is associated with favorable patient prognosis in ovarian cancer. Cancer Res 2007; 67: 3074-3084.

3. Sunde JS, Donninger H, Wu K, Johnson ME, Pestell RG, Rose GS et al. Expression profiling identifies altered expression of genes that contribute to the inhibition of transforming growth factor-\{beta\} signaling in ovarian cancer. Cancer Res 2006; 66: 8404-8412.

4. Nanjundan M CK, Zhang F, Lahad J, Kuo WL, Schmandt R, Smith-McCune K et al. Overexpression of SnoN/SkiL, amplified at the 3q26.2 locus, in ovarian cancers: a role in ovarian pathogenesis. Mol Oncol 2007; 2: 164-181.

5. Zhang TD, Chen GQ, Wang ZG, Wang ZY, Chen SJ, Chen Z. Arsenic trioxide, a therapeutic agent for APL. Oncogene 2001; 20: 7146-7153.

6. Bornstein J, Sagi S, Haj A, Harroch J, Fares F. Arsenic trioxide inhibits the growth of human ovarian carcinoma cell line. Gynecol Oncol 2005; 99: 726-729.

7. Kong B, Huang S, Wang W, Ma D, Qu X, Jiang J et al. Arsenic trioxide induces apoptosis in cisplatin-sensitive and -resistant ovarian cancer cell lines. Int J Gynecol Cancer 2005; 15 872-877.

8. Uslu R, Sanli UA, Sezgin C, Karabulut B, Terzioglu E, Omay SB et al. Arsenic trioxide-mediated cytotoxicity and apoptosis in prostate and ovarian carcinoma cell lines. Clin Cancer Res 2000; 6: 4957-4964.
9. Zhang J, Wang B. Arsenic trioxide $(\mathrm{As}(2) \mathrm{O}(3))$ inhibits peritoneal invasion of ovarian carcinoma cells in vitro and in vivo. Gynecol Oncol 2006; 103: 199-206.

10. Shackelford D, Kenific C, Blusztajn A, Waxman S, Ren R. Targeted degradation of the AML1/MDS1/EVI1 oncoprotein by arsenic trioxide. Cancer Res 2006; 66: 11360-11369.

11. Fears S, Mathieu C, Zeleznik-Le N, Huang S, Rowley JD, Nucifora G. Intergenic splicing of MDS1 and EVI1 occurs in normal tissues as well as in myeloid leukemia and produces a new member of the PR domain family. Proc Natl Acad Sci USA 1996; 93: 1642-1647.

12. Kilbey A, Bartholomew C. Evi-1 ZF1 DNA binding activity and a second distinct transcriptional repressor region are both required for optimal transformation of Rat1 fibroblasts. Oncogene 1998; 16: 2287-2291.

13. Morishita K, Parganas E, Douglass EC, Ihle JN. Unique expression of the human Evi-1 gene in an endometrial carcinoma cell line: sequence of cDNAs and structure of alternatively spliced transcripts. Oncogene 1990; 5: 963-971.

14. Kajino T, Omori E, Ishii S, Matsumoto K, Ninomiya-Tsuil J. TAK1 MAPK kinase kinase mediates transforming growth factor-beta signaling by targeting SnoN oncoprotein for degradation. J Biol Chem 2007; 282: 9475-9481.

15. Conery AR, Cao Y, Thompson EA, Townsend Jr CM, Ko TC, Luo K. Akt interacts directly with Smad3 to regulate the sensitivity to TGF-beta induced apoptosis. Nat Cell Biol 2004; 6: 366-372.

16. Wrighton $\mathrm{KH}$, Lin X, Feng XH. Critical regulation of TGFbeta signaling by Hsp90. Proc Nat Acad Sci USA 2008; 105: 9244-9249.

17. Cheng B, Yang X, Han Z, An L, Liu S. Arsenic trioxide induced the apoptosis of laryngeal cancer via down-regulation of survivin mRNA. Auris Nasus Larynx 2008; 35: 95-101.

18. Wu X, Chen Z, Liu Z, Zhou H, You Y, Li W et al. Arsenic trioxide inhibits proliferation in K562 cells by changing cell cycle and survivin expression. J Huazhong Univ Sci Technol Med Sci 2004; 24: 342-344, 353

19. Davison K, Cote S, Mader S, Miller WH. Glutathione depletion overcomes resistance to arsenic trioxide in arsenic-resistant cell lines. Leukemia 2003; 17: 931-940.

20. Salerno M, Petroutsa M, Garnier-Suillerot A. The MRP1-mediated effluxes of arsenic and antimony do not require arsenic-glutathione and antimony-glutathione complex formation. J Bioenerg Biomembr 2002; 34: 135-145.

21. Bjorkoy G, Lamark T, Johansen T. p62/SQSTM1: a missing link between protein aggregates and the autophagy machinery. Autophagy 2006; 2: 138-139.

22. Han YH, Kim SZ, Kim SH, Park WH. Suppression of arsenic trioxide-induced apoptosis in HeLa cells by N-acetylcysteine. Mol Cells 2008; 26: 18-25.

23. Hoang B, Benavides A, Shi Y, Frost P, Lichtenstein A. Effect of autophagy on multiple myeloma cell viability. Mol Cancer Ther 2009; 8: 1974-1984.

24. Qian W, Liu J, Jin J, Ni W, Xu W. Arsenic trioxide induces not only apoptosis but also autophagic cell death in leukemia cell lines via up-regulation of beclin-1. Leuk Res 2007; 31: 329-339.

25. Wu YC, Wu WK, Li Y, Yu L, Li ZJ, Wong CC et al. Inhibition of macroautophagy by bafilomycin A1 lowers proliferation and induces apoptosis in colon cancer cells. Biochem Biophys Res Commun 2009; 382: 451-456.

26. White E. Autophagic cell death unraveled: pharmacological inhibition of apoptosis and autophagy enables necrosis. Autophagy 2008; 4: 399-401.

27. Bellacosa A, de Feo D, Godwin AK, Bell DW, Cheng JQ. Altomare DA et al. Molecular alterations of the AKT2 oncogene in ovarian and breast carcinomas. Int J Cancer 1995; 64: 280-285.

28. Shayesteh L, Lu Y, Kuo WL, Baldocchi R, Godfrey T, Collins $C$ et al. PIK3CA is implicated as an oncogene in ovarian cancer. Nat Genet 1999; 21: 99-102.

29. Meng Q, Xia C, Fang J, Rojanasakul Y, Jiang BH. Role of PI3 K and AKT specific isoforms in ovarian cancer cell migration, invasion and proliferation through the p70S6K1 pathway. Cell Signal 2006; 18: 2262-2271.

30. Chen Y, Azad MB, Gibson SB. Superoxide is the major reactive oxygen species regulating autophagy. Cell Death Differ 2009; 16: 1040-1052.

31. Scherz-Shouval R, Shvets E, Elazar Z. Oxidation as a post-translational modification that regulates autophagy. Autophagy 2007; 3: 371-373.

32. Herrero-Martin G, Hoyer-Hansen M, Garcia-Garcia C, Fumarola C, Farkas T, Lopez-Rivas A et al. TAK1 activates AMPK-dependent cytoprotective autophagy in TRAIL-treated epithelial cells. EMBO J 2009; 28: 677-685.

33. Kanzawa $\mathrm{T}$, Kondo $\mathrm{Y}$, Ito $\mathrm{H}$, Kondo $\mathrm{S}$, Germano I. Induction of autophagic cell death in malignant glioma cells by arsenic trioxide. Cancer Res 2003; 63: 2103-2108.

34. Rubinsztein DC, Cuervo AM, Ravikumar B, Sarkar S, Korolchuk V, Kaushik S et al. In search of an "autophagomometer". Autophagy 2009; 5: 585-589.

35. Scarlatti F, Maffei R, Beau I, Codogno P, Ghidoni R. Role of non-canonical beclin 1-independent autophagy in cell death induced by resveratrol in human breast cancer cells. Cell Death Differ 2008; 15: 1318-1329.

36. Nishida $\mathrm{Y}$, Arakawa S, Fujitani $\mathrm{K}$, Yamaguchi $\mathrm{H}$, Mizuta $\mathrm{T}$, Kanaseki $\mathrm{T}$ et al. Discovery of Atg5/Atg7-independent alternative macroautophagy. Nature 2009; 461: $654-658$.

37. Liu ZM, Huang HS. Inhibitory role of TGIF in the $\mathrm{As}_{2} \mathrm{O}_{3}$-regulated p21 WAF1/CIP1 expression. J Biomed Sci 2008; 15: 333-342. 